\title{
MOX Fabrication Isolation Considerations
}

\author{
Eric Shaber \\ Bradley Schrader
}

August 2005

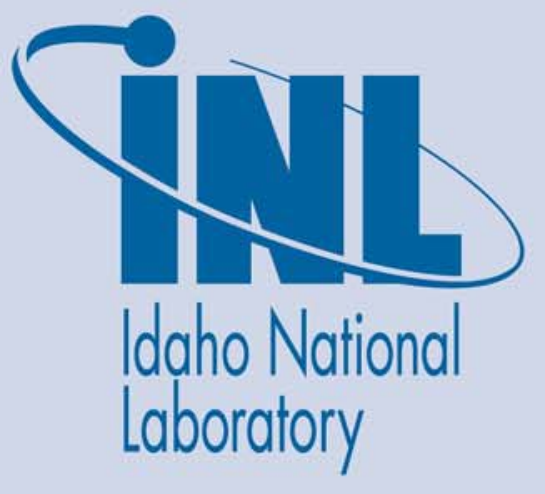

The INL is a U.S. Department of Energy National Laboratory operated by Battelle Energy Alliance 


\title{
MOX Fabrication Isolation Considerations
}

\author{
Eric Shaber \\ Bradley Schrader
}

August 2005

\author{
Idaho National Laboratory \\ Advanced Fuel Cycle Initiative \\ Idaho Falls, Idaho 83415
}

Prepared for the

U.S. Department of Energy

Office of Nuclear Energy, Science, and Technology

Under DOE Idaho Operations Office

Contract DE-AC07-05ID14517 


\begin{abstract}
This document provides a technical position on the preferred level of isolation to fabricate demonstration quantities of mixed oxide transmutation fuels. The Advanced Fuel Cycle Initiative should design and construct automated glovebox fabrication lines for this purpose. This level of isolation adequately protects the health and safety of workers and the general public for all mixed oxide (and other transmutation fuel) manufacturing efforts while retaining flexibility, allowing parallel development and setup, and minimizing capital expense.
\end{abstract}

The basis regulations, issues, and advantages/disadvantages of five potential forms of isolation are summarized here as justification for selection of the preferred technical position. 



\section{CONTENTS}

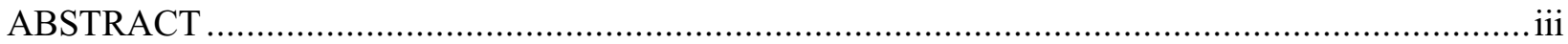

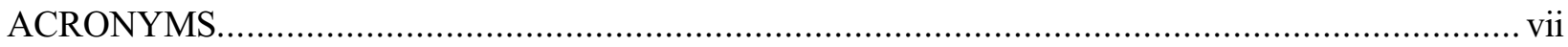

INTRODUCTION

Summary Technical Position on AFCF Approach.................................................................

POSITION ANALYSIS - BASIS DATA AND REQUIREMENTS ..............................................2

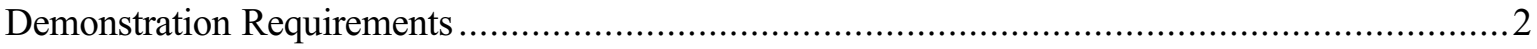

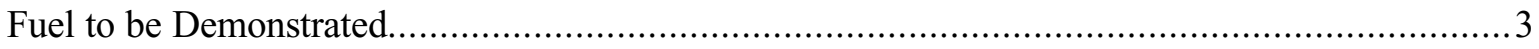

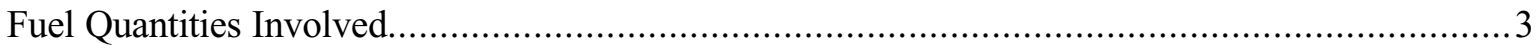

Assumptions for Fuel Quantity Calculations .................................................... 3

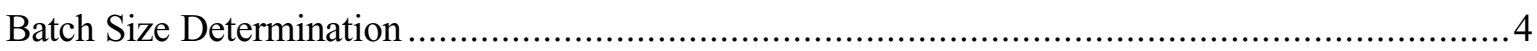

Applicable Regulations and Requirements ..................................................................... 5

Worker Radiological Exposure ....................................................................... 5

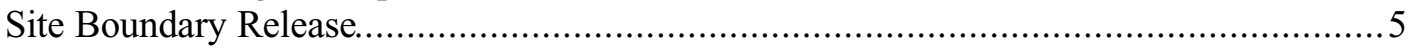

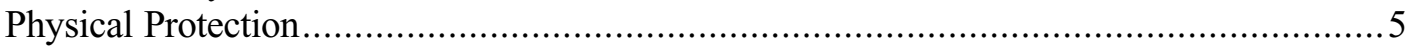

Material Control and Accounting/Proliferation Resistance ......................................6

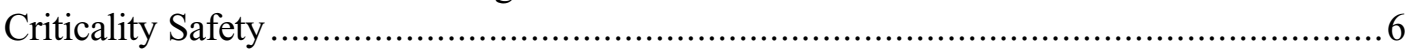

Worker Radiological Dose Calculations........................................................................ 7

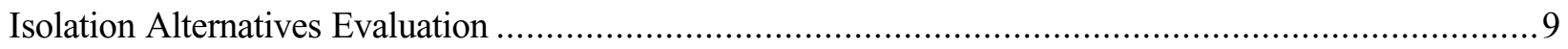

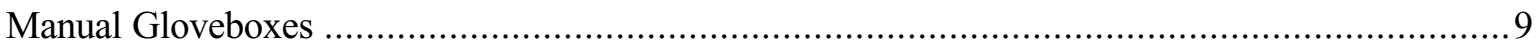

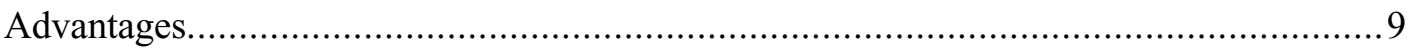

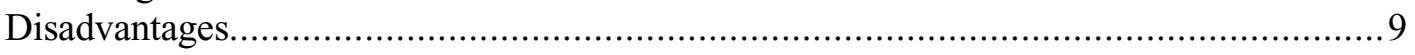

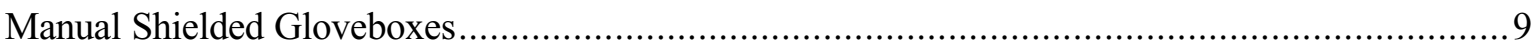

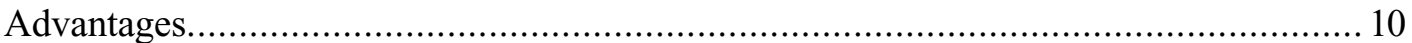

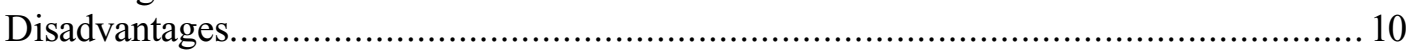

Automated Gloveboxes - Manual Maintenance........................................................................... 10

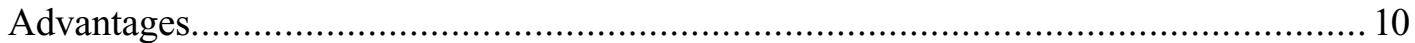

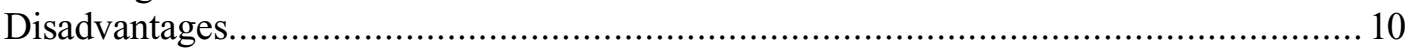




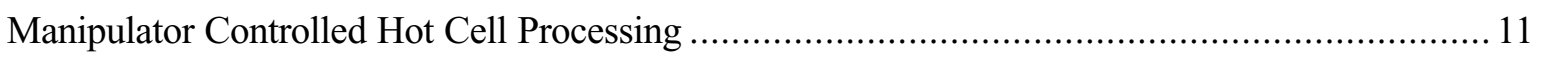

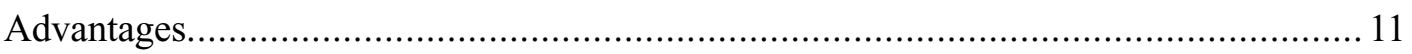

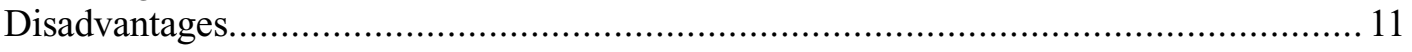

Automated Hot Cell Processing - Manipulator Maintenance................................................... 12

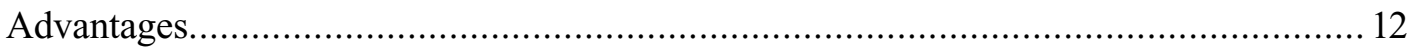

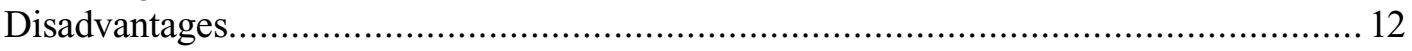

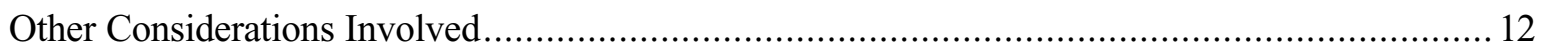

Appendix A, MOX-1 Fuel Dose Rate Calculations

Appendix B, MOX-2 Dose Rate Calculations

\section{FIGURES}

1. Distances to fuel batches for radiological dose calculations......................................................

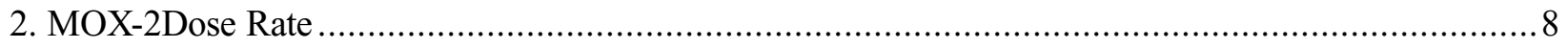

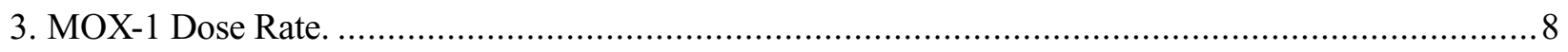

\section{TABLES}

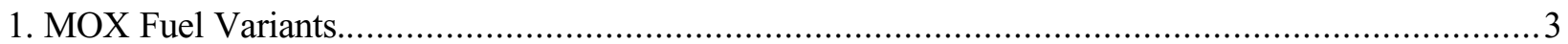

2. MOX Fuel Quantities/Lead Test Assembly................................................................... 4

3. Unshielded Glovebox Whole Body and Extremity Doses..................................................... 9 


\section{ACRONYMS}

$\begin{array}{ll}\text { AFCF } & \text { Advanced Fuel Cycle Facility } \\ \text { AFCI } & \text { Advanced Fuel Cycle Initiative } \\ \text { LTA } & \text { lead test assemblies } \\ \text { LWR } & \text { light-water reactor } \\ \text { MOX } & \text { mixed oxide (i.e. } \mathrm{U}+\mathrm{Pu}) \\ \text { QC } & \text { quality control } \\ \text { SSNM } & \text { strategic special nuclear material }\end{array}$




\section{MOX Fabrication Isolation Considerations \\ INTRODUCTION}

Mixed oxide (MOX) nuclear fuels containing $\mathrm{Pu}$ and $\mathrm{Np}$, and potentially $\mathrm{Am}$ and/or $\mathrm{Cm}$, need to be used for transmuting fission products and undesirable actinides in light-water reactors. Initial manufacturing demonstrations for such fuels are expected to occur at an Advanced Fuel Cycle Facility (AFCF) currently being defined.

Questions have arisen over the type and complexity of isolation required for manufacture of these fuels. Isolation is needed for the following:

$x \square \quad$ Prevent unacceptable worker exposure to ionizing radiation during manufacturing

$x \square \quad$ Prevent worker and/or public contamination from inadvertent release of actinides or fission products

$x \square \quad$ Ensure physical protection and control of the actinides being used in fabrication

$x \square \quad$ Provide resistance to proliferation of the actinide materials or fuel products.

Potential forms of isolation that may be considered would include the following, listed in order of increasing isolation and control:

1. Access controlled manual glovebox process lines

2. Access controlled manual shielded glovebox process lines

3. Access controlled automated glovebox process lines with area entry for maintenance/problem resolution

4. Manipulator controlled hot cell process lines

5. Automated hot cell process lines with manipulator controlled maintenance.

This document provides a technical position on the preferred level of isolation for an AFCF. The basis regulations, issues, and advantages/disadvantages of the five potential forms of isolation will be summarized as justification for selection of the preferred technical position.

\section{Summary Technical Position on Advanced Fuel Cycle Facility Approach}

The Advanced Fuel Cycle Initiative (AFCI) program should design and construct demonstration facilities made to support an automated glovebox line fabrication approach.

This technical position is supported by the following:

1. Manual glovebox operations (even shielded gloveboxes) represent an unacceptable radiological hazard to operating personnel, and a single point failure would lead to worker and possibly public contamination. 
2. The issue of criticality safety and the large number of batches involved with demonstration manufacturing make automation an attractive option that may be essential with some process operations.

3. An automated glovebox line can be placed and operated within an isolation room that provides both operator radiation protection and secondary contamination protection in the event of a glovebox leak.

4. Automated gloveboxes can be separately designed, constructed, and functionally tested in parallel with facility design and construction. The proven glovebox units may then be placed and used in the facility as modules and removed as modules when the process demonstrations are complete. Such modular designs would allow one facility to be used to demonstrate any number of different fuel processes.

\section{POSITION ANALYSIS - BASIS DATA AND REQUIREMENTS Demonstration Requirements}

Transmutation fuels are currently being fabricated on a research scale in manual glovebox lines providing fuel for irradiation tests that quantify essential fuel performance parameters. Manufacturing demonstrations will use the same or similar fabrication processes, but are inherently different than research scale fabrication in the following ways:

$x \square$ A common source characteristic feed material is used that is representative of the feed material that will be used in production.

$x \square \quad$ Front end processes are used to condition the feed material for manufacture of the desired product

$x \square \quad$ Processing vessels are of a size and arrangement to adequately show how the process would be accomplished at production scale in a fuel manufacturing plant.

$x \square \quad$ Sequential unit process operations are performed in real time to develop process throughput and efficiency baselines.

$x \square \quad$ Nuclear material control and accounting, quality control sampling and testing, and quality assurance certification functions are performed the same way they would be performed for a production operation.

$x \square$ Demonstration products are full lead test assemblies 4 to 12 feet long, ready for insertion in an operating test reactor or commercial light-water reactor (LWR).

Transmutation fuels contain fissionable actinide isotopes. In basic LWR MOX compositions, the actinide quantities are low enough that options will exist for sizing demonstration equipment. Inert matrix fuel MOX and the more advanced transmutation fuels will contain larger quantities of fissionable isotopes and process equipment sizes may be severely limited by criticality. Demonstration process equipment should be as prototypic as possible within the limitations of the facility involved. As a minimum, however, demonstration equipment must be designed to perform the process as it would be performed in a production environment. 


\section{Fuel to be Demonstrated}

Three potential MOX fuelvariants may need to be demonstrated in the AFCF as listed in Table 1. The MOX-1 composition is expected to be the first fuel demonstrated. The MOX-2 fuel form is undesirable for fuel manufacture because of its additional radiological hazards, but represents the fuel form that would result from use of both the $\mathrm{Pu} / \mathrm{Np}$ and $\mathrm{Am} / \mathrm{Cm}$ products coming from separations. MOX-3 is an estimated inert matrix composition range that would provide additional transmutation benefits by eliminating the uranium but is not yet ready to demonstrate.

Table 1. MOX Fuel Variants.

\begin{tabular}{|l|c|c|c|}
\hline \multicolumn{1}{|c|}{ Compound } & MOX-1 & MOX-2 & MOX-3* \\
\hline $\mathrm{UO}_{2}$ & $94.26 \%$ & $93.5 \%$ & 0 \\
\hline $\mathrm{PuO}_{2}$ & $5.30 \%$ & $5.30 \%$ & $14.0-20.0 \%$ \\
\hline $\mathrm{NpO}_{2}$ & $0.44 \%$ & $0.44 \%$ & $1.1-1.7 \%$ \\
\hline $\mathrm{AmO}_{2}$ & 0 & $0.69 \%$ & $1.0-2.0 \%$ \\
\hline $\mathrm{CmO}_{2}$ & 0 & $0.07 \%$ & 0 \\
\hline $\begin{array}{l}* \text { An inert matrix MOX composition is provided for reference only as it would be the bounding case for the quantity of Pu that } \\
\text { could potentially be placed in a MOX demonstration line. }\end{array}$
\end{tabular}

\section{Fuel Quantities Involved}

Current estimates of the throughput required for fuel demonstrations are based on manufacture of two lead test assemblies for a LWR in a calendar year, assuming demonstration process operations are performed in three month runs, twice during the year. With the following assumptions, an estimate of the required fuel throughput of a demonstration line (MOX-1 and MOX-2) was calculated using the mixed oxide process mass balance ${ }^{\mathrm{a}}$. The results are shown in Table 2 .

\section{Assumptions for Fuel Quantity Calculations}

$x \square$ Demonstrations will have unit process reject rates similar to those for development activities. The process will not reach steady state in a three-month run so scrap recycle and recovery operations will not be factored into processing efficiencies, therefore, the total MOX process throughput efficiency ${ }^{\mathrm{b}}$ will be approximately $73.3 \%$.

$x \square \quad$ A Lead Test Assembly for a typical $\mathrm{LWR}^{\mathrm{c}}$ will be assumed to require $1.753 \mathrm{~kg}$ of fuel per fuel rod with 264 fuel rods per assembly.

\footnotetext{
a Mass balances for transmutation fuel processes were developed to allow analysis of manufacturing efficiencies based on an input composition that take into account process losses and gains from feed conditioning, fabrication, recycle, fuel recovery, and quality control testing.

b As calculated using the Mixed Oxide Fuel Mass Balance developed for the AFCI Fuels program.

c These are generalized values for LWR MOX loading (assuming 85\% dense pellets).
} 
Table 2. MOX Fuel Quantities/Lead Test Assemblies (LTA).

\begin{tabular}{|l|l|l|l|l|l|l|l|}
\hline Fuel Type & $\begin{array}{c}\text { Total Fuel } \\
\text { Input/LTA }\end{array}$ & $\begin{array}{c}\text { Total Actinide } \\
\text { Input/LTA }\end{array}$ & $\begin{array}{c}\text { U } \\
\text { Input }\end{array}$ & $\begin{array}{c}\text { Pu } \\
\text { Input }\end{array}$ & $\begin{array}{c}\text { Np } \\
\text { Input }\end{array}$ & $\begin{array}{c}\text { Am } \\
\text { Input }\end{array}$ & $\begin{array}{c}\text { Cm } \\
\text { Input }\end{array}$ \\
\hline MOX-1 & $633.0 \mathrm{~kg}$ & $558.01 \mathrm{~kg}$ & $525.80 \mathrm{~kg}$ & $29.77 \mathrm{~kg}$ & $2.44 \mathrm{~kg}$ & 0 & 0 \\
\hline MOX-2 & $633.0 \mathrm{~kg}$ & $558.02 \mathrm{~kg}$ & $521.50 \mathrm{~kg}$ & $29.77 \mathrm{~kg}$ & $2.44 \mathrm{~kg}$ & $3.90 \mathrm{~kg}$ & $0.40 \mathrm{~kg}$ \\
\hline MOX-3 & & & $79 \mathrm{~kg} *$ & $9 \mathrm{~kg} *$ & & \\
\hline $\begin{array}{l}\text { *Pu and Np quantities for a direct replacement inert matrix fuel MOX are estimates only. A detailed mass balance is not yet } \\
\text { available as the process is still being designed. }\end{array}$
\end{tabular}

\section{Batch Size Determination}

The following assumptions are provided for determination of the demonstration batch size:

$x \square \quad$ Four days are required at the end of the fabrication campaign to assemble the lead test assembly

$x \square \quad$ An average timing of four hours/unit process for fabrication and quality control (QC) sequences should be sufficient

$x \square$ Demonstration operations will be a seven day/week, eight hours/day batch processing operation

$x \square \quad$ Demonstration facilities will be sized to allow completion of one lead test assembly from an approximate three-month fabrication campaign.

A MOX fuel blending and processing line requires 21 unit processes. QC performed for the process adds an additional 14 unit processes. With the stated assumptions, each batch processing quantity will take an average of 18 days $^{\mathrm{d}}$ to move from initial blending to finished fuel. Two batch quantities may enter the process line each day but the last two batches must enter by day 68 to be complete by the end of day 86 and allow assembly by day 90 of the campaign. Therefore, the minimum batch size for demonstration would be:

$633.0 \mathrm{~kg}$ oxide $/(2$ batches $/$ day $\times 68$ days $)=4.66 \mathrm{~kg} / \mathrm{batch}($ minimum $)$

Preliminary criticality safety studies ${ }^{1}$ indicate that the above minimum batch size is reasonable for dry process operations. If liquid compositional blending of fuel materials is determined necessary, smaller quantities would need to be processed in parallel and then combined after denitration to form the batch used for the remainder of fuel fabrication.

For simplicity of analysis, a nominal batch size of $5.0 \mathrm{~kg}$ will be used for all dose rate considerations in this document.

d Although some QC unit processes may be performed in parallel with production, the assumption is that acceptable QC results will be needed before taking the batch through the following unit processes. 


\section{Applicable Regulations and Requirements}

\section{Worker Radiological Exposure}

follows:

Radiological exposure to workers is limited to the exposure limits in 10 CFR 835, summarized as

1. Total effective annual dose of $5 \mathrm{rem} /$ year (10 CFR 835.202.1)

2. Total dose to eyes of $15 \mathrm{rem} / \mathrm{yr}(10 \mathrm{CFR} 835.202 .2)$

3. Total external dose to extremities, skin, or organs of $50 \mathrm{rem} / \mathrm{yr}(10 \mathrm{CFR} 835.202 .2 \& 4)$

4. Total dose to an unborn embryo/fetus 0.5 rem (10 CFR 835.206)

However, beyond the basic limits of the order, DOE applies several more restrictive limits for new facilities or modifications to existing facilities. Paragraph 10 CFR 835.1002 requires design objectives for exposures less than " $0.5 \mathrm{mrem} / \mathrm{hr}$ and as far below this average as reasonably achievable." It further requires that where these design objectives cannot be met, the limits shall not exceed $20 \%$ of the applicable limits itemized above.

Beyond the specific requirements in 10 CFR 835, DOE has issued DOE-STD-1098-99, Radiological Control which adds a "recommended design criteria" limiting individual worker doses to a maximum of $0.25 \mathrm{mrem} / \mathrm{hr}$ or $500 \mathrm{mrem} / \mathrm{yr}$.

\section{Site Boundary Release}

The Site boundary air release of radionuclides is limited by 40 CFR 61 . The maximum allowable dose for a member of the general public at the site boundary is $10 \mathrm{mrem} / \mathrm{year}$.

\section{Physical Protection}

As a fixed site, physical protection requirements applicable to the AFCF are specified in 10 CFR 73.40, 45, and 46 as summarized below ${ }^{\mathrm{e}}$ :

1. Provide methods to prevent unauthorized access of persons, vehicles, and materials

2. Provided methods to ensure only authorized activities and conditions within the protected area

3. Permit only authorized placement and movement of strategic special nuclear material (SSNM)

4. Control removal of only authorized and confirmed forms and amounts of SSNM

5. Provide for authorized access to assure detection of and response to unauthorized penetrations of the protected area

6. Provide response capability to assure compliance with other provisions.

e Although 10 CFR 73 is an NRC requirement, even if DOE elects not to have the facility licensed, it must be assumed that DOE would still require the facility to meet the intent of the NRC requirements. 
The key to successful design of physical protection for an AFCF will be in the definition of controlled and protected areas such that fabrication operations are not unnecessarily hindered, while physical protection requirements are fully met.

\section{Material Control and Accounting/Proliferation Resistance}

Formula quantities (quantities over $5 \mathrm{~kg}$ of $\mathrm{Pu}$ ) of strategic special nuclear materials are controlled and accounted for using the requirements of 10 CFR 74 Subpart E, unless credit for Np, Am, or Cm additions will allow a downgrading of requirements. Although an intrinsic improvement in proliferation resistance is obtained when the $\mathrm{Pu}$ is combined with other actinides, the way this would be handled in regulatory space has not been defined.

It is expected that regardless of actinide additions, a material control and accounting system will be required that achieves the following:

1. Prompt investigation of anomalies in SSNM inventories

2. Timely detection of the possible loss or diversion of SSNM

3. Rapid determination of whether a loss or diversion occurred

4. Ongoing confirmation of the presence of SSNM in assigned locations

5. Timely generation of information to aid in the recovery of SSNM in the event of an actual loss or diversion.

\section{Criticality Safety}

Criticality-safety-specific requirements are established in standard ANSI/ANS-8.1-1983 (R 1988), which is endorsed by DOE and NRC. ${ }^{2}$ These requirements are supplemented and interpreted by DOE for National Laboratories where specific criticality safety programs are implemented.

General criticality safety criteria include:

$x \square \quad$ Systems must comply with DOE's double contingency requirement if a criticality accident is credible. ${ }^{\mathrm{fg}}$

Unless specific criticality safety organization concurrence is obtained, systems must comply with a single failure limit (maximum $0.95 \mathrm{k}_{\mathrm{eff}}$ under single failure conditions) when safety margins are determined from analytic modeling.

\footnotetext{
f In this context, a criticality accident is deemed credible if both (1) a sequence of events leading to a critical condition is identified and (2) enveloping or specific, documented arguments do not demonstrate it is beyond extremely unlikely that the entire sequence could occur.

g Currently, DOE's double contingency requirement is different from the traditional double contingency principle. National standards recommend application of the double contingency principle, which involves the use of controls on two independent parameters (for example, geometry and mass, or mass and moderator) such that each control failure is unlikely. DOE's double contingency requirement is more extensive because it requires the use of multiple controls on a single parameter if it is not practical to apply the traditional double contingency principle.
} 
The NRC fuel cycle staff instituted interim guidance, ISG-10, that essentially establishes $0.90 \mathrm{k}_{\text {eff }}$ as the upper safety limit for plutonium systems whose safety is evaluated with analytical modeling unless calculation validation and bias identification are sufficiently rigorous. Such a review practice might reduce the above-quoted $0.95 \mathrm{k}_{\text {eff }}$ values for the AFCI if (1) DOE adopts similar guidance, and (2) DOE reviewers require the same calculation validation for calculations using $\mathrm{Np}, \mathrm{Am}$, and/or Cm cross section data as is required for calculations using $\mathrm{Pu}$ cross section data. ${ }^{\mathrm{h}}$ However, such issues might be avoided if criticality safety limits are based solely on $\mathrm{Pu}$ and, if present, $\mathrm{U}$, for which it appears sufficient benchmark data are available to use in validating calculation sensitivity and uncertainty.

$x \square \quad$ If a system is to be considered critically safe by mass alone, the limit must be set at no more than 75 percent of the critical mass, or, if over-batching is credible, no more than 45 percent of the critical mass.

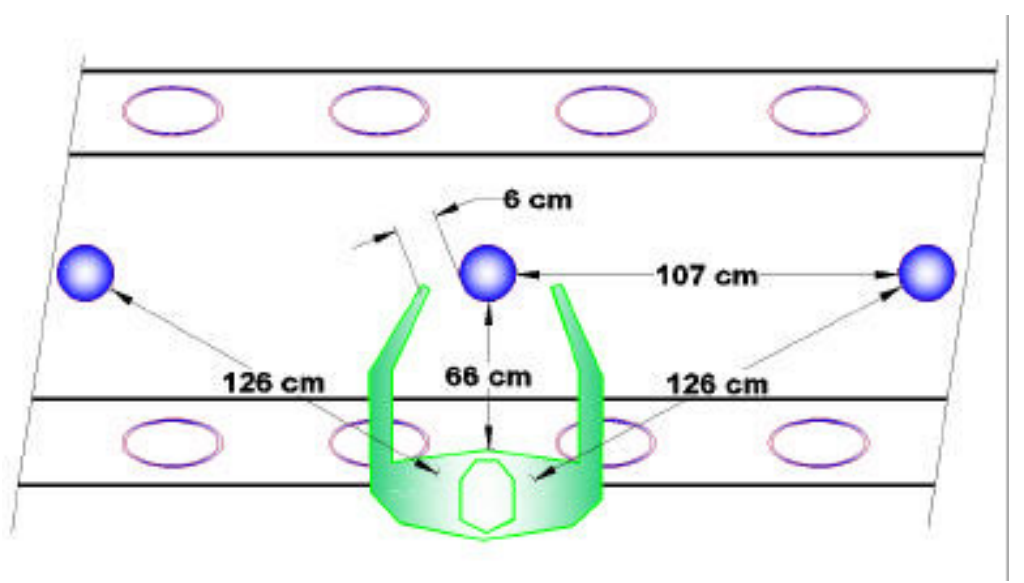

Figure 1. Distances to fuel batches for radiological dose calculations.

\section{Worker Radiological Dose Calculations}

To evaluate possible modes of operation for a new AFCF, some estimate of radiological dose is needed.

The most desirable situation would be a stable, well-trained workforce that is able to work yeararound in the facility without radiological restrictions. The requirements listed show that radiological fabrication should be designed to limit exposures to one-tenth or less of the DOE regulatory limits (500 mR whole body and $5 \mathrm{R}$ extremity). If no shielding is employed in the glovebox operation, the radiological dose that would be sustained by operators during glovebox operations can be calculated from the fuel isotopic and elemental composition and distance from the source (assuming no significant shielding from the polycarbonate glovebox walls). An estimated glovebox exposure situation (without shadow shielding) for a worker operating a unit process involving a $5 \mathrm{~kg}$ batch of fuel with other fuel batches in the unit processes $107 \mathrm{~cm}$ (42 in.) on either side is shown in Figure 1. A dose rate study ${ }^{3}$ developed the calculation routines for analyzing dose rates from reprocessed LWR fuel using other AFCI fuel compositions. The same calculation routines were used with the MOX 1 and 2 fuel compositions to

\footnotetext{
h Part of the problem is that, with the exception of one Np benchmark, no peer-reviewed benchmark data has been identified to date for $\mathrm{Np}$, Am, and/or Cm.

i In these cases minimum critical mass is determined with the system in its most reactive credible state. Similar criteria are applied for analogous controls, such as controls based on a minimum critical number of pieces.
} 
generate dose rate data specifically applicable to MOX fabrication (see Appendixes A and $\mathrm{B}^{\mathrm{j}}$ ) that is summarized in Figures 2 and 3. Using the dose rate curves with exposures from three primary sources, and assuming that the operator is physically at this location for only four hours/day, the estimated accumulated dose for MOX 1 and $2 \mathrm{f}$ fuel fabrication would be as shown in Table 3.

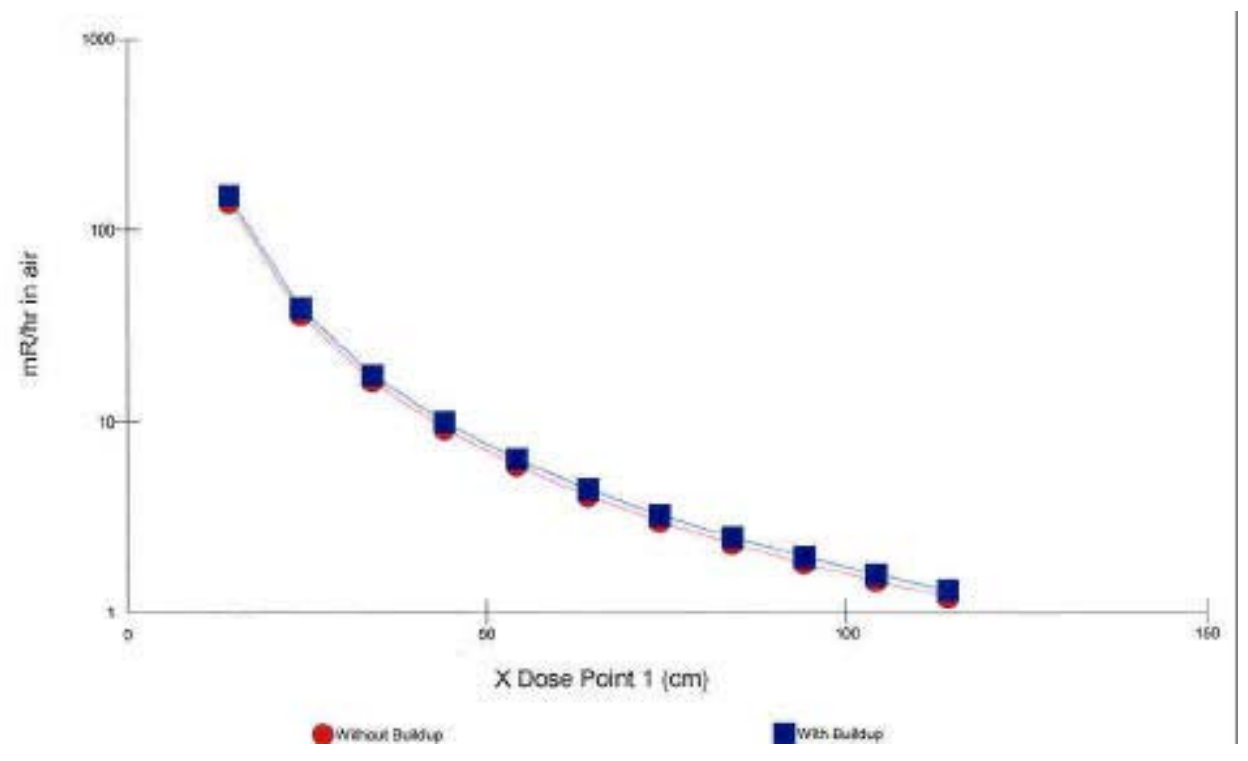

Figure 2. MOX-2 Dose Rate.

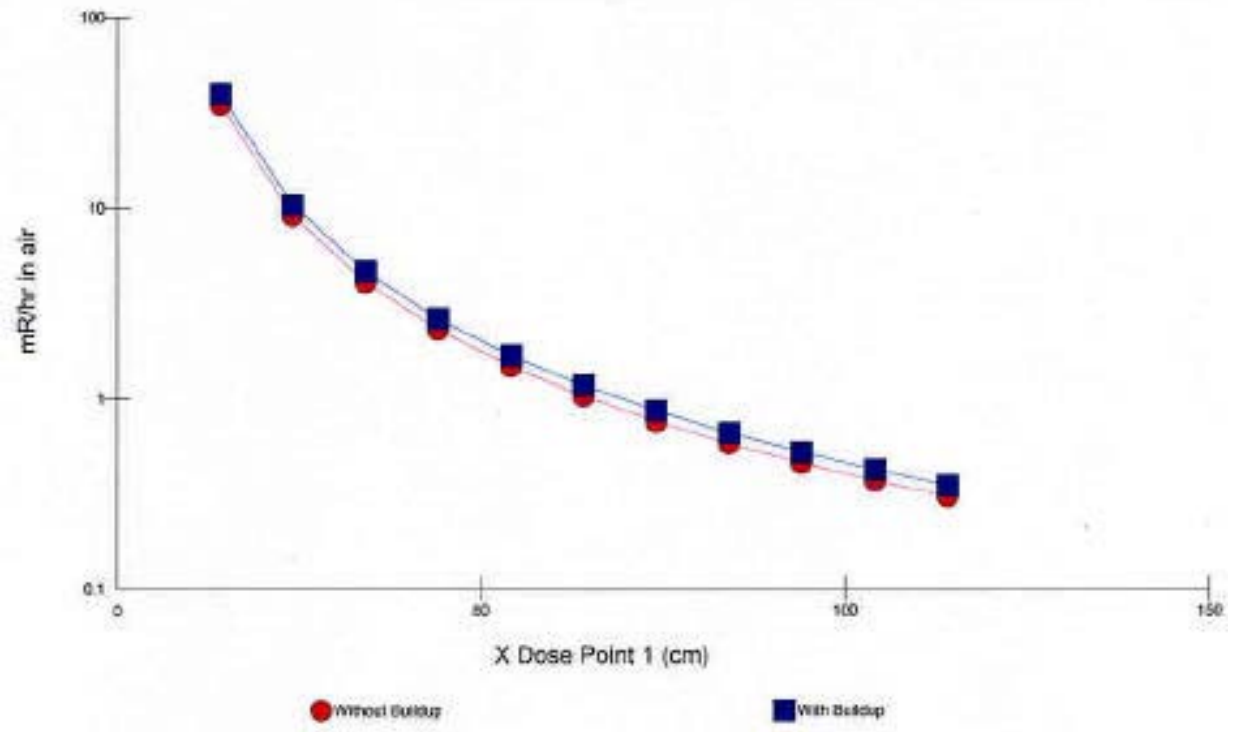

Figure 3. MOX-1 Dose Rate

\footnotetext{
${ }^{\mathrm{j}}$ Calculations provided by Bradley J. Schrader.
} 
Table 3. Unshielded Glovebox Whole Body and Extremity Doses.

\begin{tabular}{|c|l|l|l|l|}
\hline $\begin{array}{c}\text { Fuel in } \\
\text { Process }\end{array}$ & \multicolumn{1}{|c|}{$\begin{array}{c}\text { Whole Body } \\
\text { Dose/day }\end{array}$} & \multicolumn{1}{|c|}{$\begin{array}{c}\text { Extremity } \\
\text { Dose/Day }\end{array}$} & $\begin{array}{c}\text { Whole Body Dose/90 } \\
\text { days }\end{array}$ & \multicolumn{1}{c|}{$\begin{array}{c}\text { Extremity Dose/90 } \\
\text { days }\end{array}$} \\
\hline $\mathrm{MOX}-1$ & $28 \mathrm{mR}$ & $912 \mathrm{mR}$ & $2.5 \mathrm{R}$ & $82 \mathrm{R}$ \\
\hline $\mathrm{MOX}-2$ & $140 \mathrm{mR}$ & $2848 \mathrm{mR}$ & $12.6 \mathrm{R}$ & $256 \mathrm{R}$ \\
\hline
\end{tabular}

Strategic placement of shadow shielding devices (typically lead or tungsten bricks) within the gloveboxes and use of tungsten impregnated glovebox walls would greatly reduce whole body exposures but may not be sufficient to affect a major reduction in extremity (hand) exposures.

\section{Isolation Alternatives Evaluation \\ Manual Gloveboxes}

Manually operated glovebox fabrication involves the isolation of materials and unit processes within atmosphere-controlled, remote boxes or lines that are typically held at a lower atmospheric pressure than the operating area external to the box. Processes are performed manually by personnel working through glove ports strategically located along the sides of the box line.

\section{Advantages}

1. Manual gloveboxes allow direct operator control of processes and would be the closest to "handson" fabrication

2. Operators have a direct view of what is being done which simplifies intricate tasks

3. Probably the least time and capital expense is involved with line design and setup

4. Gloveboxes may be designed and tested in parallel with facility design and construction.

\section{Disadvantages}

1. Operator radiation exposure may be reduced sufficiently using shadow shielding approaches to make manufacture of MOX-1 composition fuels feasible, but MOX-2 compositions probably could not be manufactured this way

2. Worker contamination is possible from a single point failure (gloves or glove port connections

3. Physical protection, nuclear material control, and criticality safety are more difficult to ensure because of the direct human involvement in the unit processes.

\section{Manual Shielded Gloveboxes}

Manually operated shielded glovebox fabrication is quite similar to the manual operation discussed above with the exception that the gloveboxes are radiation shielded. Processes are still performed manually by personnel working through glove ports strategically located along the sides of the box line. Shielded gloveboxes are helpful in reducing whole body radiation doses through incorporation of shielding in the construction of the glovebox. 


\section{Advantages}

1. Shielded manual gloveboxes still allow direct operator control of processes

2. Operators still have a direct view of what is being done although glovebox walls may be thicker and it may be more difficult to view what is being done through heavier shielded glass windows

3. Gloveboxes may be designed and tested in parallel with facility design and construction.

\section{Disadvantages}

1. Even well designed glovebox shielding approaches would not be expected to sufficiently protect the worker from extremity exposures, especially while fabricating MOX-2 fuel

2. Operator functions would be more difficult while working around the shielding

3. Worker contamination is possible from a single point failure (gloves or glove port connections

4. Physical protection, nuclear material control, and criticality safety are more difficult to ensure because of direct human involvement in the unit processes.

\section{Automated Gloveboxes - Manual Maintenance}

This would be a process line, designed to fit within a glovebox line, in which the unit processes and material transfers are automated and the operator directs the processing electronically from behind a radiation shield, shielding wall, or physical barrier. The glove ports would be used only by maintenance personnel to repair or maintain the equipment. If the glovebox line is placed in a sealed and shielded room, a second level of isolation and contamination control would be realized.

\section{Advantages}

1. Automation provides a major reduction in both whole body and extremity radiation dose to operating personnel

2. Worker contamination from a failure of the glovebox containment is less likely because the operator is not immediately adjacent to the box and contamination may be detected and mitigated prior to personnel involvement

3. Physical protection, nuclear material control, and criticality safety are improved because material movements are automatically controlled (except during an equipment failure)

4. Overall fuel fabrication time will be minimized by automated material handling between process operations

5. Glovebox lines may be designed and tested in parallel with facility design and construction.

\section{Disadvantages}

1. Automating the unit processes within a glovebox environment would require more intricate process and equipment design and the inclusion of material handling robotics that would not be used in manual operations 
2. More time and expense is involved in the design and setup of an automated line

3. Automation involves electronics for robotics, sensors, cameras, etc. that are more prone to failure in a radiation environment

4. Although less probable, maintenance worker contamination from a single point failure (gloves or glove port connections) is still possible

5. Maintenance requirements for an automated process line may increase over those needed for a lesscomplex manually operated line, leading to higher radiation exposures for maintenance personnel. (Especially if equipment failures occur that do not allow removal of the actinide materials before repairs are initiated.)

\section{Manipulator Controlled Hot Cell Processing}

Hot cell unit processes are performed within sealed and shielded cells operating at a lower pressure or inert gas atmosphere that protects operators from radiation. Operator functions are done using handoperated manipulators that translate hand movements to the movement of manipulator end effectors within the cell. The equipment used in hot cell operations is usually rebuilt to allow simplified remote manipulation using standard end effectors.

\section{Advantages}

1. Hot cells should nearly eliminate operator radiation exposure during normal operations. Therefore, they could support extended fabrication campaigns, if required, without significant additional exposure to workers.

2. As fully sealed hard wall units, hot cells essentially preclude the possibility of worker contamination during normal operations.

3. Physical protection, and nuclear material control, are enhanced if the material balance areas can be designed to coincide with cell boundaries. Configuration control can be rigidly maintained.

4. Although criticality events have about the same probability as in manual glovebox operations, the effects of a criticality event would be minimal and should be contained within the hot cell.

5. The potential for a release at the site boundary is reduced due to the additional hard wall containment boundary.

\section{Disadvantages}

1. Hot cells represent a major facility expense and have little flexibility.

2. The time required to design and construct a hot cell facility are much greater than for a glovebox facility. Process setup and testing would need to be done after facility construction.

3. Hot cell manufacturing would be operationally much slower than glovebox lines due to the difficulty involved using manipulators.

4. Some maintenance operations may still require cell entry with corresponding radiation exposure and potential for worker contamination. 


\section{Automated Hot Cell Processing - Manipulator Maintenance}

Automated hot cell unit processes are performed within sealed and shielded cells operating at a lower pressure or inert gas atmosphere that protects operators from radiation. Operator functions are done remotely at a control panel that monitors fabrication processes and material movements. Hand-operated manipulators would be used primarily by maintenance personnel to affect repairs and perform maintenance tasks.

\section{Advantages}

1. This approach to hot cell operation should nearly eliminate both operator and maintenance personnel radiation exposures during normal operations. This capability would assist in preventing exposures for even very long process demonstrations or production operations.

2. As fully sealed hard wall units, hot cells essentially preclude the possibility of worker contamination during normal operations.

3. Both physical protection and nuclear material control should be optimum with this operational approach. Automation of nuclear material control functions is possible. Configuration control may be electronically inter-tied to the equipment operation.

4. Criticality safety is improved over manual operating approaches as it would be designed into the process line, and the effects of a criticality event would be minimal and should be contained within the hot cell.

5. The potential for a release at the site boundary is reduced due to the additional hard wall containment boundary.

6. Overall fuel fabrication time will be minimized by automated material handling between process operations. Fabrication timing would be equivalent to the automated glovebox line approach as manipulators are not required to move material between processes.

\section{Disadvantages}

1. Automated hot cell fabrication represents the most expensive and longest lead time approach. It would have minimal flexibility.

2. Process setup and testing would need to be done after facility construction.

3. Some maintenance operations may still require cell entry with corresponding radiation exposure and potential for worker contamination.

\section{Other Considerations Involved}

A fabrication demonstration designed to manufacture sufficient fuel for a lead test assembly in three months with the relatively small batch sizes dictated by criticality will be a relatively high speed manufacturing operation. The following logistics issues of managing a large number of small fabrication batches (138 for a lead test assembly) will require significant pre-planning and may dictate some level of automation: 
1. Batch movement between processes will involve containers compatible with material form, criticality concerns, and transfer ports.

2. Storage queues for unit processes that take different process times will need to be strategically placed to allow material flow without criticality issues.

3. QC test sequences will need to be integrated with manufacturing to prevent the need for large inprocess storage areas.

4. QA hold points will need to be managed such that needed verific ations occur in real time and batches are not stacked up waiting on approvals to proceed.

5. A well planned management approach for non-conforming materials will be needed that provides a pre-defined, critically-safe storage location for such materials and dictates the time they can spend in such storage before a usage decision is required.

6. Process waste stream management must be planned in detail with satellite collection sites and procedural sequences for treatment or removal from the facility. 


\section{REFERENCES}

1. Putman, V. L., "Preliminary Criticality Safety Study: Transmutation Fuel Fabrication," Idaho National Laboratory, EDF-5934, Rev. 0, July 2005.

2. ANSI/ANS-8.1-1983 (R 1988), "Nuclear Criticality Safety in Operations with Fissionable Material Outside Reactors, An American National Standard," ANS, approved October 7, 1983. Although the current edition is dated 1998, the 1983 edition is endorsed by DOE O 420.1, "Nuclear Criticality Safety," part 4.3 in Facility Safety, DOE, approved October 13, 1995; change 1 November 16, 1995; change 2 October 24, 1996. The 1983 edition is also endorsed by Regulatory Guide 3.71,'Nuclear Criticality Safety Standards for Fuels and Materials Facilities," NRC, August 1998.

3. Schrader, B. J., "Exposure Rate Calculations for Fertile and Non-Fertile Futurix Fuel," Idaho National Laboratory, EDF-5847, Rev. 0, May 2005. 


\section{Appendix A \\ MOX-1 Fuel Dose Rate Calculations}

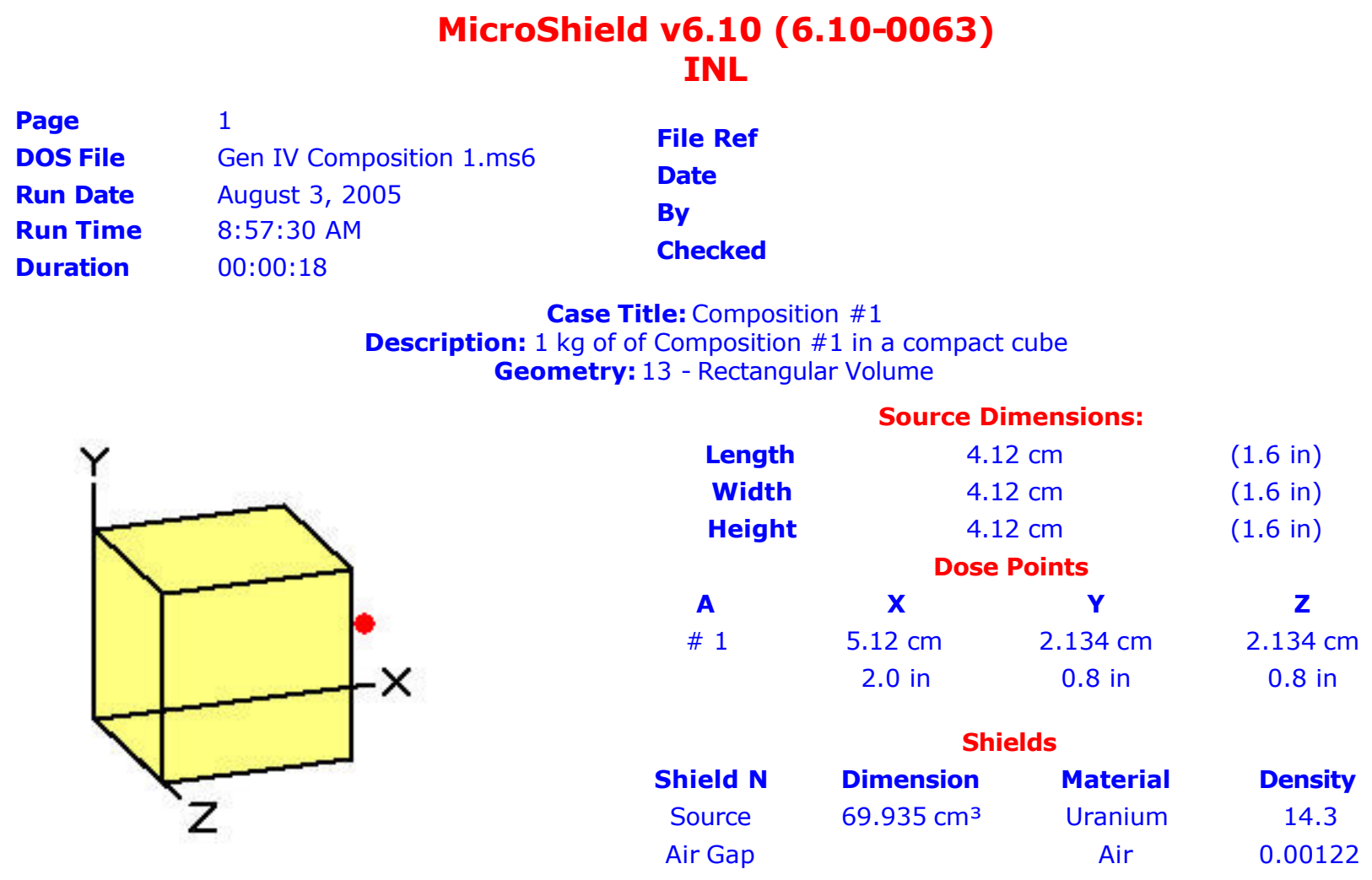

Source Input : Grouping Method - Standard Indices Number of Groups : 25

Lower Energy Cutoff : 0.015

Photons < 0.015 : Included

Library : Grove

\begin{tabular}{|c|c|c|c|c|}
\hline Nuclide & curies & becquerels & $\mu \mathrm{Ci} / \mathrm{cm}^{3}$ & $\mathrm{~Bq} / \mathrm{cm}^{3}$ \\
\hline Np-237 & $2.8100 \mathrm{e}-003$ & $1.0397 e+008$ & $4.0180 e+001$ & $1.4867 e+006$ \\
\hline Np-238 & $4.8800 e-004$ & $1.8056 e+007$ & $6.9780 e+000$ & $2.5818 e+005$ \\
\hline Np-239 & $2.0800 e-001$ & $7.6960 e+009$ & $2.9742 e+003$ & $1.1005 e+008$ \\
\hline Pu-236 & $2.2400 \mathrm{e}-003$ & $8.2880 e+007$ & $3.2030 e+001$ & $1.1851 e+006$ \\
\hline Pu-238 & $3.8300 e+001$ & $1.4171 \mathrm{e}+012$ & $5.4766 e+005$ & $2.0263 e+010$ \\
\hline Pu-239 & $1.6700 \mathrm{e}+000$ & $6.1790 e+010$ & $2.3879 e+004$ & $8.8354 e+008$ \\
\hline Pu-240 & $3.5600 e+000$ & $1.3172 e+011$ & $5.0905 e+004$ & $1.8835 e+009$ \\
\hline Pu-241 & $4.9500 e+002$ & $1.8315 e+013$ & $7.0780 e+006$ & $2.6189 e+011$ \\
\hline Pu-242 & $1.3100 \mathrm{e}-002$ & $4.8470 e+008$ & $1.8732 \mathrm{e}+002$ & $6.9308 e+006$ \\
\hline U-232 & $1.1300 \mathrm{e}-004$ & $4.1810 e+006$ & $1.6158 \mathrm{e}+000$ & $5.9784 e+004$ \\
\hline$U-233$ & $4.0000 e-007$ & $1.4800 e+004$ & $5.7196 e-003$ & $2.1163 e+002$ \\
\hline$U-234$ & $3.1000 \mathrm{e}-003$ & $1.1470 \mathrm{e}+008$ & $4.4327 e+001$ & $1.6401 e+006$ \\
\hline$U-235$ & $8.0400 e-006$ & $2.9748 e+005$ & $1.1496 \mathrm{e}-001$ & $4.2537 e+003$ \\
\hline$U-236$ & $3.5100 \mathrm{e}-004$ & $1.2987 e+007$ & $5.0190 e+000$ & $1.8570 \mathrm{e}+005$ \\
\hline
\end{tabular}




$\begin{array}{lllll}\text { U-237 } & 3.4600 e-003 & 1.2802 e+008 & 4.9475 e+001 & 1.8306 e+006 \\ \text { U-238 } & 3.1400 e-004 & 1.1618 \mathrm{e}+007 & 4.4899 \mathrm{e}+000 & 1.6613 \mathrm{e}+005 \\ \mathrm{U}-240 & 3.3700 \mathrm{e}-009 & 1.2469 \mathrm{e}+002 & 4.8188 \mathrm{e}-005 & 1.7830 \mathrm{e}+000\end{array}$

Buildup : The material reference is - Source Integration Parameters

X Direction Y Direction Z Direction
Sensitivity Analysis Summary - X Dose Point 1

\begin{tabular}{|c|c|c|c|c|c|c|}
\hline $\begin{array}{l}\text { Dose } \\
\text { Point\# }\end{array}$ & Sensitivity & $\begin{array}{l}\text { Sensitivity } \\
\text { Dimension }\end{array}$ & $\begin{array}{c}\text { Fluence Rate } \\
\text { MeV/cm²/sec } \\
\text { No Buildup }\end{array}$ & $\begin{array}{l}\text { Fluence Rate } \\
\text { MeV/cm²/sec } \\
\text { With Buildup }\end{array}$ & $\begin{array}{c}\text { Exposure Rate } \\
\text { mR/hr } \\
\text { No Buildup }\end{array}$ & $\begin{array}{c}\text { Exposure Rate } \\
\text { mR/hr } \\
\text { With Buildup }\end{array}$ \\
\hline 1 & (1 of 11 ) & $(14.12 \mathrm{~cm})$ & $1.929 e+04$ & $2.187 e+04$ & $3.466 e+01$ & $3.938 e+01$ \\
\hline 1 & (2 of 11 ) & $(24.12 \mathrm{~cm})$ & $5.034 \mathrm{e}+03$ & $5.718 e+03$ & $9.048 e+00$ & $1.030 \mathrm{e}+01$ \\
\hline 1 & (3 of 11 ) & $(34.12 \mathrm{~cm})$ & $2.259 e+03$ & $2.568 e+03$ & $4.060 e+00$ & $4.627 e+00$ \\
\hline 1 & (4 of 11 ) & $(44.12 \mathrm{~cm})$ & $1.275 e+03$ & $1.450 e+03$ & $2.292 \mathrm{e}+00$ & $2.613 e+00$ \\
\hline 1 & (5 of 11 ) & $(54.12 \mathrm{~cm})$ & $8.168 e+02$ & $9.295 e+02$ & $1.469 \mathrm{e}+00$ & $1.675 e+00$ \\
\hline 1 & (6 of 11 ) & $(64.12 \mathrm{~cm})$ & $5.673 e+02$ & $6.459 e+02$ & $1.020 \mathrm{e}+00$ & $1.164 \mathrm{e}+00$ \\
\hline 1 & (7 of 11 ) & $(74.12 \mathrm{~cm})$ & $4.167 e+02$ & $4.745 e+02$ & $7.493 e-01$ & $8.551 e-01$ \\
\hline 1 & (8 of 11 ) & $(84.12 \mathrm{~cm})$ & $3.188 e+02$ & $3.632 e+02$ & $5.733 e-01$ & $6.545 e-01$ \\
\hline 1 & (9 of 11 ) & $(94.12 \mathrm{~cm})$ & $2.517 e+02$ & $2.868 e+02$ & $4.526 e-01$ & $5.169 e-01$ \\
\hline 1 & (10 of 11 ) & $(104.12 \mathrm{~cm})$ & $2.037 e+02$ & $2.321 e+02$ & $3.663 e-01$ & $4.184 e-01$ \\
\hline 1 & (11 of 11 ) & $(114.12 \mathrm{~cm})$ & $1.682 \mathrm{e}+02$ & $1.917 e+02$ & $3.024 \mathrm{e}-01$ & $3.455 e-01$ \\
\hline
\end{tabular}

$\begin{array}{cc}\begin{array}{c}\text { Energy } \\ \text { MeV }\end{array} & \begin{array}{c}\text { Activity } \\ \text { Photons/sec }\end{array} \\ 0.03 & 1.760 \mathrm{e}+07 \\ 0.04 & 1.848 \mathrm{e}+04 \\ 0.05 & 7.736 \mathrm{e}+07 \\ 0.06 & 8.016 \mathrm{e}+08 \\ 0.08 & 1.328 \mathrm{e}+07 \\ 0.1 & 5.663 \mathrm{e}+09 \\ 0.15 & 3.448 \mathrm{e}+07 \\ 0.2 & 1.138 \mathrm{e}+09 \\ 0.3 & 1.434 \mathrm{e}+09 \\ 0.4 & 1.440 \mathrm{e}+05 \\ 0.5 & 9.832 \mathrm{e}+04 \\ 0.6 & 1.848 \mathrm{e}+04 \\ 0.8 & 1.371 \mathrm{e}+05 \\ 1.0 & 9.709 \mathrm{e}+06\end{array}$

Totals $\quad 9.189 e+09$ Sensitivity

$\begin{array}{cc}0.03 & 1.760 e+07 \\ 0.04 & 1.848 e+04 \\ 0.05 & 7.736 e+07 \\ 0.06 & 8.016 e+08 \\ 0.08 & 1.328 e+07 \\ 0.1 & 5.663 e+09\end{array}$

Results

$\begin{array}{ccc}\begin{array}{c}\text { Fluence Rate } \\ \text { MeV/cm } \mathbf{2} / \mathbf{s e c} \\ \text { No Buildup }\end{array} & \begin{array}{c}\text { Fluence Rate } \\ \text { MeV/cm } \mathbf{~ / s e c ~} \\ \text { With Buildup }\end{array} & \begin{array}{c}\text { Exposure Rate } \\ \text { mR/hr } \\ \text { No Buildup }\end{array} \\ 2.248 e-02 & 3.281 e-02 & 3.219 e-04 \\ 6.152 e-03 & 2.187 e-03 & 9.518 e-06 \\ 1.854 e+03 & 6.289 e+01 & 1.638 e-01 \\ 1.026 e+02 & 1.903 e+03 & 3.683 e+00 \\ 9.765 e+04 & 1.064 e+02 & 1.623 e-01 \\ 6.199 e+02 & 1.023 e+05 & 1.494 e+02 \\ 5.474 e+04 & 1.069 e+03 & 1.021 e+00 \\ 2.557 e+05 & 6.874 e+04 & 9.661 e+01 \\ 5.912 e+01 & 2.880 e+05 & 4.850 e+02 \\ 7.184 e+01 & 6.678 e+01 & 1.152 e-01 \\ 2.063 e+01 & 8.261 e+01 & 1.410 e-01 \\ 2.764 e+02 & 2.403 e+01 & 4.027 e-02 \\ 2.937 e+04 & 3.306 e+02 & 5.256 e-01 \\ \text { 4.405e+05 } & 3.557 e+04 & 5.414 e+01 \\ \text { Variable } & \mathbf{4 . 9 8 3 e + 0 5} & \mathbf{7 . 9 1 0 e + 0 2} \\ 5.474 e-03 & \times \text { Dose Point } 1 & (1 \text { of } 11) \\ 2.022 e-04 & 5.529 e-03 & 5.425 e-05 \\ 3.897 e+00 & 2.052 e-04 & 8.943 e-07 \\ 9.299 e+01 & 3.976 e+00 & 1.038 e-02 \\ 4.473 e+00 & 9.511 e+01 & 1.847 e-01 \\ 4.221 e+03 & 4.626 e+00 & 7.079 e-03 \\ & 4.418 e+03 & 6.458 e+00 \\ & & \end{array}$

$\begin{gathered}\text { Exposure Rate } \\ \text { mR/hr }\end{gathered}$
With Buildup
$3.252 e-04$
$9.672 e-06$
$1.675 e-01$
$3.780 e+00$
$1.683 e-01$
$1.566 e+02$
$1.761 e+00$
$1.213 e+02$
$5.464 e+02$
$1.301 e-01$
$1.622 e-01$
$4.691 e-02$
$6.288 e-01$
$6.557 e+01$
$8.967 e+02$
$(14.12 \mathrm{~cm})$
$5.479 e-05$
$9.076 e-07$
$1.059 e-02$
$1.889 e-01$
$7.320 e-03$
$6.759 e+00$




\begin{tabular}{|c|c|c|c|c|c|}
\hline $\begin{array}{c}\text { Energy } \\
\text { MeV }\end{array}$ & $\begin{array}{c}\text { Activity } \\
\text { Photons/sec }\end{array}$ & $\begin{array}{c}\text { Fluence Rate } \\
\text { MeV/ } \text { cm }^{2} / \mathrm{sec} \\
\text { No Buildup }\end{array}$ & $\begin{array}{l}\text { Fluence Rate } \\
\text { MeV/cm²/sec } \\
\text { With Buildup }\end{array}$ & $\begin{array}{c}\text { Exposure Rate } \\
\text { mR/hr } \\
\text { No Buildup }\end{array}$ & $\begin{array}{c}\text { Exposure Rate } \\
\text { mR/hr } \\
\text { With Buildup }\end{array}$ \\
\hline 0.15 & $3.448 e+07$ & $2.687 e+01$ & $4.579 e+01$ & $4.425 e-02$ & $7.541 \mathrm{e}-02$ \\
\hline 0.2 & $1.138 \mathrm{e}+09$ & $2.369 e+03$ & $2.974 \mathrm{e}+03$ & $4.180 e+00$ & $5.248 e+00$ \\
\hline 0.3 & $1.434 \mathrm{e}+09$ & $1.113 e+04$ & $1.255 e+04$ & $2.112 e+01$ & $2.380 e+01$ \\
\hline 0.4 & $1.440 \mathrm{e}+05$ & $2.603 e+00$ & $2.948 e+00$ & $5.073 e-03$ & $5.744 \mathrm{e}-03$ \\
\hline 0.5 & $9.832 e+04$ & $3.212 \mathrm{e}+00$ & $3.712 \mathrm{e}+00$ & $6.305 e-03$ & $7.287 e-03$ \\
\hline 0.6 & $1.848 e+04$ & $9.386 e-01$ & $1.103 e+00$ & $1.832 \mathrm{e}-03$ & $2.153 e-03$ \\
\hline 0.8 & $1.371 e+05$ & $1.300 e+01$ & $1.582 e+01$ & $2.472 e-02$ & $3.009 e-02$ \\
\hline 1.0 & $9.709 e+06$ & $1.420 \mathrm{e}+03$ & $1.762 \mathrm{e}+03$ & $2.618 e+00$ & $3.247 e+00$ \\
\hline \multirow[t]{2}{*}{ Totals } & $9.189 e+09$ & $1.929 e+04$ & $2.187 e+04$ & $3.466 e+01$ & $3.938 e+01$ \\
\hline & Sensitivity & Variable & X Dose Point 1 & $(2$ of 11$)$ & $(24.12 \mathrm{~cm})$ \\
\hline 0.03 & $1.760 e+07$ & $1.482 \mathrm{e}-03$ & $1.497 e-03$ & $1.469 \mathrm{e}-05$ & $1.484 \mathrm{e}-05$ \\
\hline 0.04 & $1.848 e+04$ & $5.307 e-05$ & $5.385 e-05$ & $2.347 e-07$ & $2.382 e-07$ \\
\hline 0.05 & $7.736 e+07$ & $1.010 e+00$ & $1.030 e+00$ & $2.690 e-03$ & $2.745 e-03$ \\
\hline 0.06 & $8.016 e+08$ & $2.399 e+01$ & $2.453 e+01$ & $4.764 e-02$ & $4.873 e-02$ \\
\hline 0.08 & $1.328 \mathrm{e}+07$ & $1.153 e+00$ & $1.193 e+00$ & $1.825 e-03$ & $1.888 \mathrm{e}-03$ \\
\hline 0.1 & $5.663 e+09$ & $1.090 \mathrm{e}+03$ & $1.141 \mathrm{e}+03$ & $1.668 \mathrm{e}+00$ & $1.746 e+00$ \\
\hline 0.15 & $3.448 e+07$ & $6.934 \mathrm{e}+00$ & $1.184 \mathrm{e}+01$ & $1.142 \mathrm{e}-02$ & $1.950 \mathrm{e}-02$ \\
\hline 0.2 & $1.138 e+09$ & $6.128 e+02$ & $7.701 e+02$ & $1.082 e+00$ & $1.359 e+00$ \\
\hline 0.3 & $1.434 \mathrm{e}+09$ & $2.902 e+03$ & $3.273 e+03$ & $5.504 e+00$ & $6.209 e+00$ \\
\hline 0.4 & $1.440 \mathrm{e}+05$ & $6.849 e-01$ & $7.769 e-01$ & $1.334 \mathrm{e}-03$ & $1.514 \mathrm{e}-03$ \\
\hline 0.5 & $9.832 e+04$ & $8.530 \mathrm{e}-01$ & $9.887 e-01$ & $1.674 \mathrm{e}-03$ & $1.941 \mathrm{e}-03$ \\
\hline 0.6 & $1.848 e+04$ & $2.514 \mathrm{e}-01$ & $2.968 e-01$ & $4.908 e-04$ & $5.794 e-04$ \\
\hline 0.8 & $1.371 e+05$ & $3.533 e+00$ & $4.332 e+00$ & $6.721 e-03$ & $8.239 e-03$ \\
\hline 1.0 & $9.709 e+06$ & $3.904 \mathrm{e}+02$ & $4.888 e+02$ & $7.196 \mathrm{e}-01$ & $9.010 \mathrm{e}-01$ \\
\hline \multirow[t]{2}{*}{ Totals } & $9.189 e+09$ & $5.034 e+03$ & $5.718 e+03$ & $9.048 e+00$ & $1.030 \mathrm{e}+01$ \\
\hline & Sensitivity & Variable & X Dose Point 1 & (3 of 11 ) & $(34.12 \mathrm{~cm})$ \\
\hline 0.03 & $1.760 e+07$ & $6.668 e-04$ & $6.735 e-04$ & $6.608 e-06$ & $6.675 e-06$ \\
\hline 0.04 & $1.848 e+04$ & $2.375 e-05$ & $2.410 \mathrm{e}-05$ & $1.051 \mathrm{e}-07$ & $1.066 \mathrm{e}-07$ \\
\hline 0.05 & $7.736 e+07$ & $4.511 e-01$ & $4.603 e-01$ & $1.202 \mathrm{e}-03$ & $1.226 \mathrm{e}-03$ \\
\hline 0.06 & $8.016 e+08$ & $1.071 \mathrm{e}+01$ & $1.095 e+01$ & $2.127 e-02$ & $2.175 e-02$ \\
\hline 0.08 & $1.328 e+07$ & $5.150 e-01$ & $5.326 e-01$ & $8.150 e-04$ & $8.429 e-04$ \\
\hline 0.1 & $5.663 e+09$ & $4.872 e+02$ & $5.100 e+02$ & $7.453 e-01$ & $7.803 e-01$ \\
\hline 0.15 & $3.448 e+07$ & $3.098 e+00$ & $5.295 e+00$ & $5.101 e-03$ & $8.720 e-03$ \\
\hline 0.2 & $1.138 \mathrm{e}+09$ & $2.740 e+02$ & $3.445 e+02$ & $4.837 e-01$ & $6.081 e-01$ \\
\hline 0.3 & $1.434 \mathrm{e}+09$ & $1.301 e+03$ & $1.469 e+03$ & $2.469 e+00$ & $2.786 e+00$ \\
\hline 0.4 & $1.440 e+05$ & $3.082 \mathrm{e}-01$ & $3.499 e-01$ & $6.006 e-04$ & $6.818 e-04$ \\
\hline 0.5 & $9.832 e+04$ & $3.853 e-01$ & $4.472 \mathrm{e}-01$ & $7.563 e-04$ & $8.777 e-04$ \\
\hline 0.6 & $1.848 e+04$ & $1.140 \mathrm{e}-01$ & $1.348 e-01$ & $2.225 e-04$ & $2.631 \mathrm{e}-04$ \\
\hline 0.8 & $1.371 e+05$ & $1.611 e+00$ & $1.981 e+00$ & $3.065 e-03$ & $3.768 e-03$ \\
\hline 1.0 & $9.709 e+06$ & $1.788 e+02$ & $2.247 e+02$ & $3.296 \mathrm{e}-01$ & $4.143 e-01$ \\
\hline \multirow[t]{2}{*}{ Totals } & $9.189 e+09$ & $2.259 e+03$ & $2.568 e+03$ & $4.060 \mathrm{e}+00$ & $4.627 e+00$ \\
\hline & Sensitivity & Variable & X Dose Point 1 & $(4$ of 11$)$ & $(44.12 \mathrm{~cm})$ \\
\hline 0.03 & $1.760 e+07$ & $3.757 e-04$ & $3.795 e-04$ & $3.724 \mathrm{e}-06$ & $3.761 e-06$ \\
\hline 0.04 & $1.848 e+04$ & $1.337 e-05$ & $1.357 e-05$ & $5.913 e-08$ & $6.001 e-08$ \\
\hline 0.05 & $7.736 e+07$ & $2.538 e-01$ & $2.590 e-01$ & $6.762 \mathrm{e}-04$ & $6.900 e-04$ \\
\hline 0.06 & $8.016 e+08$ & $6.024 \mathrm{e}+00$ & $6.161 e+00$ & $1.196 \mathrm{e}-02$ & $1.224 \mathrm{e}-02$ \\
\hline 0.08 & $1.328 \mathrm{e}+07$ & $2.898 e-01$ & $2.998 e-01$ & $4.587 e-04$ & $4.744 e-04$ \\
\hline
\end{tabular}




\begin{tabular}{|c|c|c|c|c|c|}
\hline $\begin{array}{c}\text { Energy } \\
\text { MeV }\end{array}$ & $\begin{array}{c}\text { Activity } \\
\text { Photons/sec }\end{array}$ & $\begin{array}{c}\text { Fluence Rate } \\
\mathrm{MeV} / \mathrm{cm}^{2} / \mathrm{sec} \\
\text { No Buildup }\end{array}$ & $\begin{array}{l}\text { Fluence Rate } \\
\text { MeV/cm²/sec } \\
\text { With Buildup }\end{array}$ & $\begin{array}{c}\text { Exposure Rate } \\
\text { mR/hr } \\
\text { No Buildup }\end{array}$ & $\begin{array}{c}\text { Exposure Rate } \\
\text { mR/hr } \\
\text { With Buildup }\end{array}$ \\
\hline 0.1 & $5.663 e+09$ & $2.743 e+02$ & $2.872 e+02$ & $4.196 \mathrm{e}-01$ & $4.393 e-01$ \\
\hline 0.15 & $3.448 e+07$ & $1.744 \mathrm{e}+00$ & $2.984 \mathrm{e}+00$ & $2.872 e-03$ & $4.914 e-03$ \\
\hline 0.2 & $1.138 \mathrm{e}+09$ & $1.544 \mathrm{e}+02$ & $1.942 e+02$ & $2.725 e-01$ & $3.427 e-01$ \\
\hline 0.3 & $1.434 \mathrm{e}+09$ & $7.343 e+02$ & $8.289 e+02$ & $1.393 e+00$ & $1.572 \mathrm{e}+00$ \\
\hline 0.4 & $1.440 \mathrm{e}+05$ & $1.743 e-01$ & $1.979 e-01$ & $3.395 e-04$ & $3.856 e-04$ \\
\hline 0.5 & $9.832 e+04$ & $2.182 \mathrm{e}-01$ & $2.535 e-01$ & $4.284 e-04$ & $4.975 e-04$ \\
\hline 0.6 & $1.848 \mathrm{e}+04$ & $6.467 e-02$ & 7.657e-02 & $1.262 \mathrm{e}-04$ & $1.494 \mathrm{e}-04$ \\
\hline 0.8 & $1.371 e+05$ & $9.172 \mathrm{e}-01$ & $1.130 \mathrm{e}+00$ & $1.745 e-03$ & $2.149 e-03$ \\
\hline 1.0 & $9.709 e+06$ & $1.020 e+02$ & $1.285 e+02$ & $1.881 \mathrm{e}-01$ & $2.369 e-01$ \\
\hline Totals & $\begin{array}{c}\text { 9.189e+09 } \\
\text { Sensitivity }\end{array}$ & $\begin{array}{c}\mathbf{1 . 2 7 5 e + 0 3} \\
\text { Variable }\end{array}$ & $\begin{array}{c}\mathbf{1 . 4 5 0 e + 0 3} \\
\times \text { Dose Point } 1\end{array}$ & $\begin{array}{c}\mathbf{2 . 2 9 2 e + 0 0} \\
(5 \text { of } 11)\end{array}$ & $\begin{array}{c}\mathbf{2 . 6 1 3 e + 0 0} \\
(54.12 \mathrm{~cm})\end{array}$ \\
\hline 0.03 & $1.760 e+07$ & $2.402 e-04$ & $2.426 e-04$ & $2.380 e-06$ & $2.404 \mathrm{e}-06$ \\
\hline 0.04 & $1.848 e+04$ & $8.547 e-06$ & $8.674 e-06$ & $3.780 e-08$ & $3.836 e-08$ \\
\hline 0.05 & $7.736 e+07$ & $1.623 e-01$ & $1.656 \mathrm{e}-01$ & $4.323 e-04$ & $4.411 e-04$ \\
\hline 0.06 & $8.016 e+08$ & $3.851 e+00$ & $3.939 e+00$ & $7.649 e-03$ & $7.823 e-03$ \\
\hline 0.08 & $1.328 e+07$ & $1.854 \mathrm{e}-01$ & $1.917 e-01$ & $2.933 e-04$ & $3.034 \mathrm{e}-04$ \\
\hline 0.1 & $5.663 e+09$ & $1.755 e+02$ & $1.837 e+02$ & $2.684 \mathrm{e}-01$ & $2.811 e-01$ \\
\hline 0.15 & $3.448 e+07$ & $1.116 \mathrm{e}+00$ & $1.911 e+00$ & $1.837 e-03$ & $3.146 e-03$ \\
\hline 0.2 & $1.138 \mathrm{e}+09$ & $9.881 e+01$ & $1.243 e+02$ & $1.744 \mathrm{e}-01$ & $2.194 \mathrm{e}-01$ \\
\hline 0.3 & $1.434 \mathrm{e}+09$ & $4.705 e+02$ & $5.312 e+02$ & $8.924 \mathrm{e}-01$ & $1.008 \mathrm{e}+00$ \\
\hline 0.4 & $1.440 e+05$ & $1.118 \mathrm{e}-01$ & $1.270 \mathrm{e}-01$ & $2.178 e-04$ & $2.474 \mathrm{e}-04$ \\
\hline 0.5 & $9.832 e+04$ & $1.402 \mathrm{e}-01$ & $1.629 e-01$ & $2.751 e-04$ & $3.197 e-04$ \\
\hline 0.6 & $1.848 e+04$ & $4.159 e-02$ & $4.927 e-02$ & $8.117 e-05$ & $9.616 e-05$ \\
\hline 0.8 & $1.371 \mathrm{e}+05$ & $5.910 \mathrm{e}-01$ & $7.287 e-01$ & $1.124 \mathrm{e}-03$ & $1.386 \mathrm{e}-03$ \\
\hline 1.0 & $9.709 e+06$ & $6.585 e+01$ & $8.306 e+01$ & $1.214 \mathrm{e}-01$ & $1.531 \mathrm{e}-01$ \\
\hline \multirow[t]{2}{*}{ Totals } & $9.189 e+09$ & $8.168 e+02$ & $9.295 e+02$ & $1.469 \mathrm{e}+00$ & $1.675 e+00$ \\
\hline & Sensitivity & Variable & X Dose Point 1 & $(6$ of 11$)$ & $(64.12 \mathrm{~cm})$ \\
\hline 0.03 & $1.760 e+07$ & $1.664 \mathrm{e}-04$ & $1.680 e-04$ & $1.649 \mathrm{e}-06$ & $1.665 e-06$ \\
\hline 0.04 & $1.848 e+04$ & $5.924 e-06$ & $6.012 e-06$ & $2.620 e-08$ & $2.659 e-08$ \\
\hline 0.05 & $7.736 e+07$ & $1.125 \mathrm{e}-01$ & $1.148 \mathrm{e}-01$ & $2.997 e-04$ & $3.058 e-04$ \\
\hline 0.06 & $8.016 e+08$ & $2.670 e+00$ & $2.731 e+00$ & $5.304 e-03$ & $5.425 e-03$ \\
\hline 0.08 & $1.328 \mathrm{e}+07$ & $1.286 \mathrm{e}-01$ & $1.330 \mathrm{e}-01$ & $2.034 \mathrm{e}-04$ & $2.104 \mathrm{e}-04$ \\
\hline 0.1 & $5.663 e+09$ & $1.217 e+02$ & $1.275 e+02$ & $1.862 \mathrm{e}-01$ & $1.950 \mathrm{e}-01$ \\
\hline 0.15 & $3.448 e+07$ & $7.741 e-01$ & $1.327 e+00$ & $1.275 \mathrm{e}-03$ & $2.185 e-03$ \\
\hline 0.2 & $1.138 \mathrm{e}+09$ & $6.857 e+01$ & $8.631 e+01$ & $1.210 \mathrm{e}-01$ & $1.523 e-01$ \\
\hline 0.3 & $1.434 \mathrm{e}+09$ & $3.268 e+02$ & $3.690 e+02$ & $6.198 \mathrm{e}-01$ & $7.000 e-01$ \\
\hline 0.4 & $1.440 e+05$ & $7.770 \mathrm{e}-02$ & $8.829 e-02$ & $1.514 \mathrm{e}-04$ & $1.720 \mathrm{e}-04$ \\
\hline 0.5 & $9.832 e+04$ & $9.752 \mathrm{e}-02$ & $1.134 \mathrm{e}-01$ & $1.914 \mathrm{e}-04$ & $2.225 e-04$ \\
\hline 0.6 & $1.848 e+04$ & $2.896 e-02$ & $3.432 \mathrm{e}-02$ & $5.652 e-05$ & $6.700 \mathrm{e}-05$ \\
\hline 0.8 & $1.371 \mathrm{e}+05$ & $4.121 \mathrm{e}-01$ & $5.085 e-01$ & $7.838 e-04$ & $9.672 e-04$ \\
\hline 1.0 & $9.709 e+06$ & $4.597 e+01$ & $5.804 e+01$ & $8.473 e-02$ & $1.070 \mathrm{e}-01$ \\
\hline \multirow[t]{2}{*}{ Totals } & $9.189 e+09$ & $5.673 e+02$ & $6.459 e+02$ & $1.020 \mathrm{e}+00$ & $1.164 \mathrm{e}+00$ \\
\hline & Sensitivity & Variable & X Dose Point 1 & (7 of 11 ) & $(74.12 \mathrm{~cm})$ \\
\hline 0.03 & $1.760 e+07$ & $1.219 \mathrm{e}-04$ & $1.231 \mathrm{e}-04$ & $1.208 \mathrm{e}-06$ & $1.220 \mathrm{e}-06$ \\
\hline 0.04 & $1.848 e+04$ & $4.343 e-06$ & $4.407 e-06$ & $1.921 \mathrm{e}-08$ & $1.949 e-08$ \\
\hline 0.05 & $7.736 e+07$ & $8.249 e-02$ & $8.417 e-02$ & $2.197 e-04$ & $2.242 \mathrm{e}-04$ \\
\hline 0.06 & $8.016 e+08$ & $1.958 e+00$ & $2.003 e+00$ & $3.889 e-03$ & $3.978 e-03$ \\
\hline
\end{tabular}




$\begin{array}{cc}\begin{array}{c}\text { Energy } \\ \text { MeV }\end{array} & \begin{array}{c}\text { Activity } \\ \text { Photons } / \text { sec }\end{array} \\ 0.08 & 1.328 e+07 \\ 0.1 & 5.663 e+09 \\ 0.15 & 3.448 \mathrm{e}+07 \\ 0.2 & 1.138 \mathrm{e}+09 \\ 0.3 & 1.434 \mathrm{e}+09 \\ 0.4 & 1.440 \mathrm{e}+05 \\ 0.5 & 9.832 \mathrm{e}+04 \\ 0.6 & 1.848 \mathrm{e}+04 \\ 0.8 & 1.371 \mathrm{e}+05 \\ 1.0 & 9.709 \mathrm{e}+06 \\ \text { Totals } & \mathbf{9 . 1 8 9 e}+09 \\ & \text { Sensitivity } \\ 0.03 & 1.760 \mathrm{e}+07 \\ 0.04 & 1.848 \mathrm{e}+04 \\ 0.05 & 7.736 \mathrm{e}+07 \\ 0.06 & 8.016 \mathrm{e}+08 \\ 0.08 & 1.328 \mathrm{e}+07 \\ 0.1 & 5.663 \mathrm{e}+09 \\ 0.15 & 3.448 \mathrm{e}+07 \\ 0.2 & 1.138 \mathrm{e}+09 \\ 0.3 & 1.434 \mathrm{e}+09 \\ 0.4 & 1.440 \mathrm{e}+05 \\ 0.5 & 9.832 \mathrm{e}+04 \\ 0.6 & 1.848 \mathrm{e}+04 \\ 0.8 & 1.371 \mathrm{e}+05 \\ 1.0 & 9.709 \mathrm{e}+06 \\ \text { Totals } & 9.189 \mathrm{e}+09 \\ 0.04\end{array}$

Totals $\quad 9.189 \mathrm{e}+09$

Sensitivity

$0.03 \quad 1.760 e+07$

$0.04 \quad 1.848 \mathrm{e}+04$

$0.05 \quad 7.736 e+07$

$0.06 \quad 8.016 e+08$

$0.08 \quad 1.328 \mathrm{e}+07$

$0.1 \quad 5.663 e+09$

$0.15 \quad 3.448 e+07$

$0.2 \quad 1.138 \mathrm{e}+09$

$0.3 \quad 1.434 \mathrm{e}+09$

$0.4 \quad 1.440 \mathrm{e}+05$

$0.5 \quad 9.832 e+04$

$0.6 \quad 1.848 \mathrm{e}+04$

$0.8 \quad 1.371 \mathrm{e}+05$

$1.0 \quad 9.709 \mathrm{e}+06$

Totals $\quad 9.189 e+09$

$\begin{array}{ll}0.03 & 1.760 e+07 \\ 0.04 & 1.848 e+04 \\ 0.05 & 7.736 e+07\end{array}$

\section{Fluence Rate} $\mathrm{MeV} / \mathrm{cm}^{2} / \mathrm{sec}$ No Buildup

9.430e-02

$8.930 e+01$

5.680e-01

$5.034 e+01$

$2.400 \mathrm{e}+02$

5.711e-02

7.172e-02

2.131e-02

3.036e-01

$3.389 e+01$

4.167e+02

Variable

9.298e-05

3.317e-06

6.302e-02

$1.496 \mathrm{e}+00$

$7.208 \mathrm{e}-02$

$6.827 e+01$

4.343e-01

$3.850 e+01$

$1.836 \mathrm{e}+02$

4.372e-02

5.494e-02

$1.633 e-02$

$2.328 \mathrm{e}-01$

$2.601 e+01$

3.188e+02

Variable

7.321e-05

2.614e-06

4.969e-02

$1.180 \mathrm{e}+00$

5.685e-02

$5.386 e+01$

3. $427 \mathrm{e}-01$

$3.038 \mathrm{e}+01$

$1.450 \mathrm{e}+02$

3.453e-02

4.341e-02

1.291e-02

1.842e-01

$2.059 e+01$

$\mathbf{2 . 5 1 7 e + 0 2}$

Variable

5.908e-05

2.112e-06

4.016e-02
Results

\section{Fluence Rate \\ $\mathrm{MeV} / \mathrm{cm}^{2} / \mathrm{sec}$}

With Buildup

9.755e-02

$9.353 e+01$

9.744e-01

$6.338 e+01$

$2.711 e+02$

6.490e-02

8.339e-02

2.527e-02

3.748e-01

$4.282 \mathrm{e}+01$

4.745e+02

$X$ Dose Point 1

9.392e-05

3.366e-06

6.431e-02

$1.531 \mathrm{e}+00$

7.457e-02

$7.151 e+01$

7.456e-01

$4.849 \mathrm{e}+01$

$2.075 e+02$

4.970e-02

6.389e-02

1.937e-02

2.876e-01

$3.289 e+01$

$3.632 e+02$

$X$ Dose Point 1

7.394e-05

2.653e-06

5.070e-02

$1.207 \mathrm{e}+00$

5.882e-02

$5.641 e+01$

5.887e-01

$3.828 \mathrm{e}+01$

$1.638 \mathrm{e}+02$

3.926e-02

5.050e-02

1.532e-02

2. $276 \mathrm{e}-01$

$2.604 \mathrm{e}+01$

$\mathbf{2 . 8 6 8 e + 0 2}$

$X$ Dose Point 1

5.968e-05

2.143e-06

4.098e-02

\section{Exposure Rate $\mathrm{mR} / \mathrm{hr}$ \\ No Buildup}

1.492e-04

$1.366 \mathrm{e}-01$

9.354e-04

8.884e-02

4.553e-01

$1.113 \mathrm{e}-04$

$1.408 \mathrm{e}-04$

4.159e-05

5.774e-04

6.247e-02

7.493e-01

(8 of 11)

9.215e-07

$1.467 \mathrm{e}-08$

$1.679 \mathrm{e}-04$

2.972e-03

$1.141 \mathrm{e}-04$

$1.044 \mathrm{e}-01$

7.152e-04

6.794e-02

3.483e-01

8.518e-05

$1.078 \mathrm{e}-04$

3. $188 \mathrm{e}-05$

4.429e-04

4.794e-02

5.733e-01

(9 of 11)

7.255e-07

$1.156 \mathrm{e}-08$

$1.324 \mathrm{e}-04$

$2.344 \mathrm{e}-03$

8.996e-05

8.240e-02

5.643e-04

5.362e-02

2.750e-01

6.728e-05

8.521e-05

2.520e-05

3.503e-04

$3.795 \mathrm{e}-02$

4.526e-01

(10 of 11 )

5.855e-07

9.340e-09

$1.070 \mathrm{e}-04$

\section{Exposure Rate $\mathrm{mR} / \mathrm{hr}$}

With Buildup

1.544e-04

1.431e-01

1.605e-03

$1.119 e-01$

5.142e-01

1.265e-04

$1.637 \mathrm{e}-04$

4.932e-05

7.130e-04

7.894e-02

8.551e-01

$(84.12 \mathrm{~cm})$

9.308e-07

1.489e-08

$1.713 e-04$

3.040e-03

$1.180 \mathrm{e}-04$

$1.094 \mathrm{e}-01$

$1.228 \mathrm{e}-03$

8.558e-02

3.935e-01

9.683e-05

$1.254 \mathrm{e}-04$

3.781e-05

5. $471 \mathrm{e}-04$

6.062e-02

6.545e-01

$(94.12 \mathrm{~cm})$

7.328e-07

$1.173 e-08$

1.351e-04

2.397e-03

9.308e-05

8.631e-02

9.695e-04

6.756e-02

3.108e-01

7.650e-05

9.913e-05

2.990e-05

4.330e-04

4.800e-02

5.169e-01

$(104.12 \mathrm{~cm})$

5.914e-07

9.479e-09

1.092e-04 


\begin{tabular}{|c|c|c|c|c|c|}
\hline \multirow[b]{2}{*}{$\begin{array}{c}\text { Energy } \\
\text { MeV }\end{array}$} & \multirow[b]{2}{*}{$\begin{array}{c}\text { Activity } \\
\text { Photons/sec }\end{array}$} & & \multirow[b]{2}{*}{$\begin{array}{c}\text { Exposure Rate } \\
\text { mR/hr } \\
\text { With Buildup }\end{array}$} \\
\hline & & $\begin{array}{c}\text { Fluence Rate } \\
\text { MeV/cm²/sec } \\
\text { No Buildup }\end{array}$ & $\begin{array}{l}\text { Fluence Rate } \\
\text { MeV/cm²/sec } \\
\text { With Buildup }\end{array}$ & $\begin{array}{c}\text { Exposure Rate } \\
\text { mR/hr } \\
\text { No Buildup }\end{array}$ & \\
\hline 0.06 & $8.016 e+08$ & $9.538 e-01$ & $9.757 e-01$ & $1.894 e-03$ & $1.938 e-03$ \\
\hline 0.08 & $1.328 \mathrm{e}+07$ & $4.596 e-02$ & $4.756 e-02$ & $7.274 \mathrm{e}-05$ & $7.526 e-05$ \\
\hline 0.1 & $5.663 e+09$ & $4.355 e+01$ & $4.562 e+01$ & $6.663 e-02$ & $6.980 e-02$ \\
\hline 0.15 & $3.448 e+07$ & $2.772 \mathrm{e}-01$ & $4.765 e-01$ & $4.564 e-04$ & $7.847 e-04$ \\
\hline 0.2 & $1.138 \mathrm{e}+09$ & $2.458 e+01$ & $3.098 e+01$ & $4.338 e-02$ & $5.467 e-02$ \\
\hline 0.3 & $1.434 \mathrm{e}+09$ & $1.173 e+02$ & $1.326 \mathrm{e}+02$ & $2.226 \mathrm{e}-01$ & $2.515 e-01$ \\
\hline 0.4 & $1.440 \mathrm{e}+05$ & $2.796 \mathrm{e}-02$ & $3.179 e-02$ & $5.447 e-05$ & $6.195 e-05$ \\
\hline 0.5 & $9.832 e+04$ & $3.516 e-02$ & $4.091 e-02$ & $6.901 e-05$ & $8.030 e-05$ \\
\hline 0.6 & $1.848 e+04$ & $1.046 \mathrm{e}-02$ & $1.241 \mathrm{e}-02$ & $2.041 e-05$ & $2.423 e-05$ \\
\hline 0.8 & $1.371 \mathrm{e}+05$ & $1.493 e-01$ & $1.846 \mathrm{e}-01$ & $2.840 \mathrm{e}-04$ & $3.511 e-04$ \\
\hline 1.0 & $9.709 e+06$ & $1.669 \mathrm{e}+01$ & $2.113 e+01$ & $3.077 e-02$ & $3.895 e-02$ \\
\hline \multirow[t]{2}{*}{ Totals } & $9.189 e+09$ & $2.037 e+02$ & $2.321 e+02$ & $3.663 e-01$ & $4.184 \mathrm{e}-01$ \\
\hline & Sensitivity & Variable & X Dose Point 1 & (11 of 11 ) & $(114.12 \mathrm{~cm})$ \\
\hline 0.03 & $1.760 \mathrm{e}+07$ & $4.865 e-05$ & $4.913 e-05$ & $4.821 e-07$ & $4.870 e-07$ \\
\hline 0.04 & $1.848 e+04$ & $1.741 \mathrm{e}-06$ & $1.766 \mathrm{e}-06$ & $7.698 e-09$ & $7.813 e-09$ \\
\hline 0.05 & $7.736 e+07$ & $3.311 \mathrm{e}-02$ & $3.379 e-02$ & $8.821 e-05$ & $9.001 e-05$ \\
\hline 0.06 & $8.016 e+08$ & $7.866 e-01$ & $8.047 e-01$ & $1.562 e-03$ & $1.598 \mathrm{e}-03$ \\
\hline 0.08 & $1.328 \mathrm{e}+07$ & $3.792 \mathrm{e}-02$ & $3.924 \mathrm{e}-02$ & $6.000 e-05$ & $6.209 e-05$ \\
\hline 0.1 & $5.663 e+09$ & $3.593 e+01$ & $3.765 e+01$ & $5.497 e-02$ & $5.759 e-02$ \\
\hline 0.15 & $3.448 e+07$ & $2.287 e-01$ & $3.935 e-01$ & $3.766 e-04$ & $6.481 e-04$ \\
\hline 0.2 & $1.138 e+09$ & $2.028 e+01$ & $2.557 e+01$ & $3.580 e-02$ & $4.514 e-02$ \\
\hline 0.3 & $1.434 \mathrm{e}+09$ & $9.688 e+01$ & $1.095 e+02$ & $1.838 \mathrm{e}-01$ & $2.077 e-01$ \\
\hline 0.4 & $1.440 e+05$ & $2.309 e-02$ & $2.626 e-02$ & $4.499 e-05$ & $5.117 e-05$ \\
\hline 0.5 & $9.832 e+04$ & $2.905 e-02$ & $3.381 e-02$ & $5.702 e-05$ & $6.636 e-05$ \\
\hline 0.6 & $1.848 e+04$ & $8.644 \mathrm{e}-03$ & $1.026 \mathrm{e}-02$ & $1.687 e-05$ & $2.003 e-05$ \\
\hline 0.8 & $1.371 \mathrm{e}+05$ & $1.235 \mathrm{e}-01$ & $1.527 e-01$ & $2.348 e-04$ & $2.904 \mathrm{e}-04$ \\
\hline 1.0 & $9.709 e+06$ & $1.381 e+01$ & $1.748 e+01$ & $2.545 e-02$ & $3.223 e-02$ \\
\hline Totals & $9.189 \mathrm{e}+09$ & $1.682 e+02$ & $1.917 e+02$ & $3.024 \mathrm{e}-01$ & $3.455 e-01$ \\
\hline
\end{tabular}




\title{
Appendix B
}

\section{MOX - 2 Dose Rate Calculations}

\author{
MicroShield v6.10 (6.10-0063) \\ INL
}

$\begin{array}{lll}\text { Page } & 1 & \text { File Ref } \\ \text { Dos File } & \text { Gen IV Composition 2.ms6 } & \text { Date } \\ \text { Run Date } & \text { August 3, 2005 } & \text { By } \\ \text { Run Time } & 8: 59: 36 \text { AM } & \text { Checked } \\ \text { Duration } & 00: 00: 18 & \end{array}$

Case Title: Composition \#2

Description: $1 \mathrm{~kg}$ of of Composition \#2 in a compact cube Geometry: 13 - Rectangular Volume

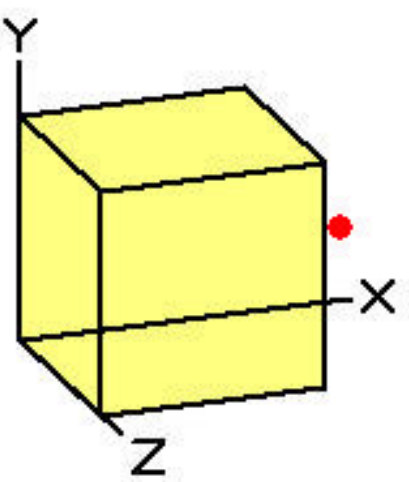

\section{Length \\ Width \\ Height}

A

\# 1

Shield N

Source

Air Gap
Source Dimensions:
$4.12 \mathrm{~cm}$
(1.6 in)
(1.6 in)
(1.6 in)
$4.12 \mathrm{~cm}$

Dose Points

\begin{tabular}{|c|c|}
\hline $\mathbf{x}$ & $\mathbf{Y}$ \\
\hline $5.12 \mathrm{~cm}$ & $2.134 \mathrm{~cm}$ \\
\hline $2.0 \mathrm{in}$ & 0.8 in \\
\hline \multicolumn{2}{|c|}{ Shields } \\
\hline Dimension & Material \\
\hline $69.935 \mathrm{~cm}^{3}$ & $\begin{array}{c}\text { Uranium } \\
\text { Air }\end{array}$ \\
\hline
\end{tabular}

\section{Z}

$2.134 \mathrm{~cm}$ 0.8 in

Density

14.28

0.00122

Source Input : Grouping Method - Standard Indices Number of Groups : 25

Lower Energy Cutoff : 0.015

Photons < 0.015 : Included

Nuclide
Am-241
Am-242m
Am-243
Cm-242
Cm-243
Cm-244
Cm-245
Cm-246
Np-237
Np-238
Np-239
Pu-236
Pu-238

Nuclide

curies

$1.9600 \mathrm{e}+001$

$1.2000 \mathrm{e}-001$

$2.5500 \mathrm{e}-001$

$3.0400 \mathrm{e}-001$

3.2700e-001

$7.3800 e+001$

$1.1500 \mathrm{e}-002$

4.6500e-003

$2.8100 e-003$

4.8800e-004

2.0800e-001

2.2400e-003

$3.8300 e+001$
Library : Grove

\begin{tabular}{|c|c|c|}
\hline becquerels & $\mu \mathrm{Ci} / \mathrm{cm}^{3}$ & $\mathrm{~Bq} / \mathrm{cm}^{3}$ \\
\hline $7.2520 e+011$ & $2.8026 \mathrm{e}+005$ & $1.0370 \mathrm{e}+010$ \\
\hline $4.4400 e+009$ & $1.7159 e+003$ & $6.3488 e+007$ \\
\hline $9.4350 e+009$ & $3.6463 e+003$ & $1.3491 \mathrm{e}+008$ \\
\hline $1.1248 \mathrm{e}+010$ & $4.3469 e+003$ & $1.6084 \mathrm{e}+008$ \\
\hline $1.2099 \mathrm{e}+010$ & $4.6758 e+003$ & $1.7300 \mathrm{e}+008$ \\
\hline $2.7306 e+012$ & $1.0553 e+006$ & $3.9045 e+010$ \\
\hline $4.2550 e+008$ & $1.6444 \mathrm{e}+002$ & $6.0843 e+006$ \\
\hline $1.7205 e+008$ & $6.6491 e+001$ & $2.4602 e+006$ \\
\hline $1.0397 e+008$ & $4.0180 e+001$ & $1.4867 e+006$ \\
\hline $1.8056 e+007$ & $6.9780 e+000$ & $2.5818 \mathrm{e}+005$ \\
\hline $7.6960 e+009$ & $2.9742 \mathrm{e}+003$ & $1.1005 e+008$ \\
\hline $8.2880 e+007$ & $3.2030 \mathrm{e}+001$ & $1.1851 \mathrm{e}+006$ \\
\hline $1.4171 e+012$ & $5.4766 e+005$ & $2.0263 e+010$ \\
\hline
\end{tabular}


Source Input : Grouping Method - Standard Indices Number of Groups : 25

Lower Energy Cutoff : 0.015

Photons < 0.015 : Included Library : Grove

$\begin{array}{cc}\text { Nuclide } & \text { curies } \\ \text { Pu-239 } & 1.6700 \mathrm{e}+000 \\ \text { Pu-240 } & 3.5600 \mathrm{e}+000 \\ \mathrm{Pu}-241 & 4.9500 \mathrm{e}+002 \\ \mathrm{Pu}-242 & 1.3100 \mathrm{e}-002 \\ \mathrm{U}-232 & 1.1200 \mathrm{e}-004 \\ \mathrm{U}-233 & 3.9700 \mathrm{e}-007 \\ \mathrm{U}-234 & 3.0700 \mathrm{e}-003 \\ \mathrm{U}-235 & 7.9700 \mathrm{e}-006 \\ \mathrm{U}-236 & 3.4800 \mathrm{e}-004 \\ \mathrm{U}-237 & 3.4300 \mathrm{e}-003 \\ \mathrm{U}-238 & 3.1100 \mathrm{e}-004 \\ \mathrm{U}-240 & 3.3400 \mathrm{e}-009\end{array}$

becquerels $\quad \mathbf{\mu C i} / \mathbf{c m}^{3}$

$\mathrm{Bq} / \mathrm{cm}^{3}$

$6.1790 e+010$

$1.3172 \mathrm{e}+011$

$1.8315 e+013$

$4.8470 \mathrm{e}+008$

$4.1440 \mathrm{e}+006$

$1.4689 e+004$

$1.1359 \mathrm{e}+008$

$2.9489 e+005$

$1.2876 \mathrm{e}+007$

$1.2691 \mathrm{e}+008$

$1.1507 e+007$

$1.2358 e+002$
$2.3879 \mathrm{e}+004$

$5.0905 e+004$

$7.0780 e+006$

$1.8732 \mathrm{e}+002$

$1.6015 \mathrm{e}+000$

5.6767e-003

$4.3898 \mathrm{e}+001$

$1.1396 \mathrm{e}-001$

$4.9761 \mathrm{e}+000$

$4.9046 \mathrm{e}+001$

$4.4470 e+000$

4.7759e-005
$8.8354 \mathrm{e}+008$

$1.8835 \mathrm{e}+009$

$2.6189 e+011$

$6.9308 \mathrm{e}+006$

$5.9255 e+004$

$2.1004 \mathrm{e}+002$

$1.6242 \mathrm{e}+006$

$4.2167 e+003$

$1.8412 \mathrm{e}+005$

$1.8147 \mathrm{e}+006$

$1.6454 \mathrm{e}+005$

$1.7671 \mathrm{e}+000$
$X$ Direction

$Y$ Direction

Z Direction
Buildup : The material reference is - Source Integration Parameters

$\begin{array}{cc}\begin{array}{c}\text { Dose } \\ \text { Point\# }\end{array} & \text { Sensitivity } \\ 1 & (1 \text { of } 11) \\ 1 & (2 \text { of } 11) \\ 1 & (3 \text { of } 11) \\ 1 & (4 \text { of } 11) \\ 1 & (5 \text { of } 11) \\ 1 & (6 \text { of } 11) \\ 1 & (7 \text { of } 11) \\ 1 & (8 \text { of } 11) \\ 1 & (9 \text { of } 11) \\ 1 & (10 \text { of } 11) \\ 1 & (11 \text { of } 11)\end{array}$

Sensi Sensitivity

$(14.12 \mathrm{~cm})$

$(24.12 \mathrm{~cm})$

$(34.12 \mathrm{~cm})$

$(44.12 \mathrm{~cm})$

$(54.12 \mathrm{~cm})$

$(64.12 \mathrm{~cm})$

$(74.12 \mathrm{~cm})$

$(84.12 \mathrm{~cm})$

$(94.12 \mathrm{~cm})$

$(104.12 \mathrm{~cm})$

$(114.12 \mathrm{~cm})$
Activity

$\begin{array}{cc}\begin{array}{c}\text { Energy } \\ \text { MeV }\end{array} & \begin{array}{c}\text { Activity } \\ \text { Photons/sec }\end{array} \\ 0.03 & 1.819 \mathrm{e}+10 \\ 0.04 & 5.381 \mathrm{e}+08 \\ 0.05 & 1.015 \mathrm{e}+08 \\ 0.06 & 2.633 \mathrm{e}+11 \\ 0.08 & 6.272 \mathrm{e}+09 \\ 0.1 & 1.176 \mathrm{e}+10 \\ 0.15 & 1.406 \mathrm{e}+08 \\ 0.2 & 2.815 \mathrm{e}+09\end{array}$

\begin{tabular}{|c|}
\hline $\begin{array}{c}\text { Fluence Rate } \\
\text { MeV/ } \mathrm{cm}^{2} / \mathrm{sec} \\
\text { No Buildup }\end{array}$ \\
\hline $3.389 e+01$ \\
\hline $6.299 e+01$ \\
\hline $8.098 e+01$ \\
\hline $6.103 e+05$ \\
\hline $4.854 e+04$ \\
\hline $2.031 e+05$ \\
\hline $2.532 e+03$ \\
\hline $1.356 e+05$ \\
\hline
\end{tabular}

Results

$\begin{gathered}\text { Fluence Rate } \\ \text { MeV/cm }\end{gathered}$
With Buildup
$3.424 e+01$
$6.401 e+01$
$8.281 e+01$
$6.263 e+05$
$5.034 e+04$
$2.128 e+05$
$4.367 e+03$
$1.703 e+05$

$\begin{array}{cc}\begin{array}{c}\text { Fluence Rate } \\ \text { MeV/cm²/sec } \\ \text { No Buildup }\end{array} & \begin{array}{c}\text { Fluence Rate } \\ \text { MeV/cm²/sec } \\ \text { With Buildup }\end{array} \\ 7.399 e+04 & 8.028 e+04 \\ 1.919 e+04 & 2.084 e+04 \\ 8.585 e+03 & 9.327 e+03 \\ 4.837 e+03 & 5.257 e+03 \\ 3.096 e+03 & 3.365 e+03 \\ 2.148 e+03 & 2.336 e+03 \\ 1.577 e+03 & 1.715 e+03 \\ 1.206 e+03 & 1.312 e+03 \\ 9.514 e+02 & 1.035 e+03 \\ 7.695 e+02 & 8.373 e+02 \\ 6.350 e+02 & 6.910 e+02\end{array}$

$\begin{gathered}\text { Exposure Rate } \\ \mathbf{m R} / \mathbf{h r}\end{gathered}$
No Buildup
$1.384 \mathrm{e}+02$
$3.588 \mathrm{e}+01$
$1.606 \mathrm{e}+01$
$9.047 \mathrm{e}+00$
$5.790 \mathrm{e}+00$
$4.018 \mathrm{e}+00$
$2.949 \mathrm{e}+00$
$2.255 \mathrm{e}+00$
$1.779 \mathrm{e}+00$
$1.439 \mathrm{e}+00$
$1.187 \mathrm{e}+00$

\section{Exposure Rate $\mathrm{mR} / \mathrm{hr}$ With Buildup \\ $1.500 \mathrm{e}+02$ \\ 3. $892 \mathrm{e}+01$ \\ $1.742 \mathrm{e}+01$ \\ $9.820 \mathrm{e}+00$ \\ $6.287 e+00$ \\ $4.364 \mathrm{e}+00$ \\ $3.203 e+00$ \\ $2.450 e+00$ \\ $1.933 e+00$ \\ $1.564 \mathrm{e}+00$ \\ $1.291 e+00$}




\begin{tabular}{|c|c|}
\hline $\begin{array}{c}\text { Energy } \\
\text { MeV }\end{array}$ & $\begin{array}{c}\text { Activity } \\
\text { Photons/sec }\end{array}$ \\
\hline 0.3 & $3.225 e+09$ \\
\hline 0.4 & $1.427 e+05$ \\
\hline 0.5 & $9.832 e+04$ \\
\hline 0.6 & $1.848 e+04$ \\
\hline 0.8 & $1.371 e+05$ \\
\hline 1.0 & $9.709 e+06$ \\
\hline \multirow[t]{2}{*}{ Totals } & $3.063 e+11$ \\
\hline & Sensitivity \\
\hline 0.03 & $1.819 e+10$ \\
\hline 0.04 & $5.381 e+08$ \\
\hline 0.05 & $1.015 e+08$ \\
\hline 0.06 & $2.633 e+11$ \\
\hline 0.08 & $6.272 e+09$ \\
\hline 0.1 & $1.176 e+10$ \\
\hline 0.15 & $1.406 e+08$ \\
\hline 0.2 & $2.815 e+09$ \\
\hline 0.3 & $3.225 e+09$ \\
\hline 0.4 & $1.427 e+05$ \\
\hline 0.5 & $9.832 e+04$ \\
\hline 0.6 & $1.848 \mathrm{e}+04$ \\
\hline 0.8 & $1.371 e+05$ \\
\hline 1.0 & $9.709 e+06$ \\
\hline \multirow[t]{2}{*}{ Totals } & $3.063 e+11$ \\
\hline & Sensitivity \\
\hline 0.03 & $1.819 e+10$ \\
\hline 0.04 & $5.381 e+08$ \\
\hline 0.05 & $1.015 e+08$ \\
\hline 0.06 & $2.633 e+11$ \\
\hline 0.08 & $6.272 e+09$ \\
\hline 0.1 & $1.176 \mathrm{e}+10$ \\
\hline 0.15 & $1.406 e+08$ \\
\hline 0.2 & $2.815 e+09$ \\
\hline 0.3 & $3.225 e+09$ \\
\hline 0.4 & $1.427 e+05$ \\
\hline 0.5 & $9.832 e+04$ \\
\hline 0.6 & $1.848 e+04$ \\
\hline 0.8 & $1.371 \mathrm{e}+05$ \\
\hline 1.0 & $9.709 e+06$ \\
\hline \multirow[t]{2}{*}{ Totals } & $3.063 e+11$ \\
\hline & Sensitivity \\
\hline 0.03 & $1.819 \mathrm{e}+10$ \\
\hline 0.04 & $5.381 e+08$ \\
\hline 0.05 & $1.015 e+08$ \\
\hline 0.06 & $2.633 e+11$ \\
\hline 0.08 & $6.272 e+09$ \\
\hline 0.1 & $1.176 \mathrm{e}+10$ \\
\hline 0.15 & $1.406 \mathrm{e}+08$ \\
\hline
\end{tabular}

\section{Fluence Rate $\mathrm{MeV} / \mathrm{cm}^{2} / \mathrm{sec}$ No Buildup}

$5.757 e+05$

$5.868 \mathrm{e}+01$

$7.193 e+01$

$2.065 e+01$

$2.767 e+02$

$2.940 e+04$

1.606e+06

Variable

$5.706 e+00$

$5.912 e+00$

$5.127 e+00$

$3.059 e+04$

$2.117 e+03$

$8.781 e+03$

$1.098 \mathrm{e}+02$

$5.869 e+03$

$2.507 e+04$

$2.584 \mathrm{e}+00$

$3.217 e+00$

9.398e-01

$1.301 \mathrm{e}+01$

$1.422 \mathrm{e}+03$

\section{$7.399 e+04$}

Variable

$1.545 e+00$

$1.551 \mathrm{e}+00$

$1.329 \mathrm{e}+00$

$7.890 e+03$

$5.458 \mathrm{e}+02$

$2.268 e+03$

$2.832 e+01$

$1.519 e+03$

$6.535 e+03$

6.799e-01

8.541e-01

2.518e-01

$3.538 \mathrm{e}+00$

$3.909 e+02$

\section{$1.919 e+04$}

Variable

6.951e-01

$6.945 \mathrm{e}-01$

5.935e-01

$3.522 \mathrm{e}+03$

$2.437 e+02$

$1.013 e+03$

$1.265 \mathrm{e}+01$
Results

\section{Fluence Rate \\ $\mathrm{MeV} / \mathrm{cm}^{2} / \mathrm{sec}$}

With Buildup

$6.486 e+05$

$6.629 e+01$

8.271e+01

$2.406 e+01$

$3.309 e+02$

$3.560 \mathrm{e}+04$

1.749e+06

$X$ Dose Point 1

$5.764 \mathrm{e}+00$

$6.000 \mathrm{e}+00$

$5.231 \mathrm{e}+00$

$3.129 \mathrm{e}+04$

$2.189 e+03$

$9.190 \mathrm{e}+03$

$1.870 \mathrm{e}+02$

$7.369 \mathrm{e}+03$

$2.825 e+04$

$2.926 \mathrm{e}+00$

$3.717 e+00$

$1.105 \mathrm{e}+00$

$1.584 \mathrm{e}+01$

$1.764 \mathrm{e}+03$

$8.028 e+04$

$X$ Dose Point 1

$1.560 \mathrm{e}+00$

$1.574 \mathrm{e}+00$

$1.356 \mathrm{e}+00$

$8.069 e+03$

$5.643 e+02$

$2.374 \mathrm{e}+03$

$4.836 e+01$

$1.908 \mathrm{e}+03$

$7.371 e+03$

7.712e-01

9.900e-01

$2.972 \mathrm{e}-01$

$4.337 e+00$

$4.894 \mathrm{e}+02$

2.084e+04

$X$ Dose Point 1

7.020e-01

7.047e-01

$6.056 \mathrm{e}-01$

$3.602 e+03$

$2.520 \mathrm{e}+02$

$1.061 \mathrm{e}+03$

$2.163 e+01$

\section{Exposure Rate $\mathrm{mR} / \mathrm{hr}$ \\ No Buildup}

$1.092 e+03$

1.143e-01

$1.412 \mathrm{e}-01$

4.032e-02

5.262e-01

$5.420 e+01$

2.991e+03

(1 of 11 )

5.655e-02

2.615e-02

1.366e-02

$6.076 \mathrm{e}+01$

$3.349 \mathrm{e}+00$

$1.343 e+01$

1.807e-01

$1.036 \mathrm{e}+01$

$4.755 e+01$

5.035e-03

$6.314 \mathrm{e}-03$

$1.834 \mathrm{e}-03$

2.475e-02

$2.621 e+00$

$1.384 \mathrm{e}+02$

(2 of 11)

1.531e-02

6.862e-03

$3.540 \mathrm{e}-03$

$1.567 \mathrm{e}+01$

8.636e-01

$3.470 e+00$

4.664e-02

$2.680 e+00$

$1.240 \mathrm{e}+01$

$1.325 \mathrm{e}-03$

1.677e-03

$4.914 \mathrm{e}-04$

$6.729 \mathrm{e}-03$

7.205e-01

$\mathbf{3 . 5 8 8 e + 0 1}$

(3 of 11)

$6.888 \mathrm{e}-03$

$3.071 \mathrm{e}-03$

$1.581 \mathrm{e}-03$

$6.995 e+00$

3.856e-01

$1.550 \mathrm{e}+00$

2.084e-02

\section{Exposure Rate $\mathrm{mR} / \mathrm{hr}$}

With Buildup

$1.230 \mathrm{e}+03$

1.292e-01

1.624e-01

4.697e-02

6.295e-01

$6.563 e+01$

$3.255 e+03$

$(14.12 \mathrm{~cm})$

5.712e-02

2.654e-02

1.394e-02

$6.214 \mathrm{e}+01$

$3.463 e+00$

$1.406 \mathrm{e}+01$

3.080e-01

$1.301 \mathrm{e}+01$

5.359e+01

5.702e-03

7.296e-03

2.156e-03

3.012e-02

$3.251 \mathrm{e}+00$

$1.500 e+02$

$(24.12 \mathrm{~cm})$

1.547e-02

6.963e-03

3.612e-03

$1.603 e+01$

8.930e-01

$3.632 e+00$

7.963e-02

$3.368 \mathrm{e}+00$

$1.398 \mathrm{e}+01$

1.503e-03

$1.943 e-03$

5.801e-04

$8.250 \mathrm{e}-03$

9.021e-01

$\mathbf{3 . 8 9 2 e + 0 1}$

$(34.12 \mathrm{~cm})$

6.958e-03

3.117e-03

$1.613 e-03$

$7.154 \mathrm{e}+00$

3.988e-01

$1.623 e+00$

3.562e-02 


$\begin{array}{cc}\begin{array}{c}\text { Energy } \\ \text { MeV }\end{array} & \begin{array}{c}\text { Activity } \\ \text { Photons/sec }\end{array} \\ 0.2 & 2.815 \mathrm{e}+09 \\ 0.3 & 3.225 \mathrm{e}+09 \\ 0.4 & 1.427 \mathrm{e}+05 \\ 0.5 & 9.832 \mathrm{e}+04 \\ 0.6 & 1.848 \mathrm{e}+04 \\ 0.8 & 1.371 \mathrm{e}+05 \\ 1.0 & 9.709 \mathrm{e}+06 \\ \text { Totals } & \mathbf{3 . 0 6 3 e + 1 1} \\ & \text { Sensitivity } \\ 0.03 & 1.819 \mathrm{e}+10 \\ 0.04 & 5.381 \mathrm{e}+08 \\ 0.05 & 1.015 \mathrm{e}+08 \\ 0.06 & 2.633 \mathrm{e}+11 \\ 0.08 & 6.272 \mathrm{e}+09 \\ 0.1 & 1.176 \mathrm{e}+10 \\ 0.15 & 1.406 \mathrm{e}+08 \\ 0.2 & 2.815 \mathrm{e}+09 \\ 0.3 & 3.225 \mathrm{e}+09 \\ 0.4 & 1.427 \mathrm{e}+05 \\ 0.5 & 9.832 \mathrm{e}+04 \\ 0.6 & 1.848 \mathrm{e}+04 \\ 0.8 & 1.371 \mathrm{e}+05 \\ 1.0 & 9.709 \mathrm{e}+06 \\ \text { Totals } & \mathbf{3 . 0 6 3 e + 1 1}\end{array}$

Sensitivity

$0.03 \quad 1.819 e+10$

$0.04 \quad 5.381 e+08$

$0.05 \quad 1.015 e+08$

$0.06 \quad 2.633 e+11$

$0.08 \quad 6.272 e+09$

$0.1 \quad 1.176 \mathrm{e}+10$

$0.15 \quad 1.406 \mathrm{e}+08$

$0.2 \quad 2.815 e+09$

$0.3 \quad 3.225 e+09$

$0.4 \quad 1.427 e+05$

$0.5 \quad 9.832 e+04$

$0.6 \quad 1.848 \mathrm{e}+04$

$0.8 \quad 1.371 \mathrm{e}+05$

$1.0 \quad 9.709 \mathrm{e}+06$

Totals $\quad 3.063 e+11$

Sensitivity

$0.03 \quad 1.819 e+10$

$0.04 \quad 5.381 e+08$

$0.05 \quad 1.015 \mathrm{e}+08$

$0.06 \quad 2.633 e+11$

$0.08 \quad 6.272 e+09$

$0.1 \quad 1.176 \mathrm{e}+10$

\section{Fluence Rate $\mathrm{MeV} / \mathrm{cm}^{2} / \mathrm{sec}$}

No Buildup

$6.791 e+02$

$2.931 e+03$

3.060e-01

3.858e-01

1.141e-01

$1.613 e+00$

$1.790 e+02$

8.585e+03

Variable

3.917e-01

3. $909 \mathrm{e}-01$

3.340e-01

$1.981 e+03$

$1.371 \mathrm{e}+02$

$5.705 e+02$

$7.124 \mathrm{e}+00$

$3.826 \mathrm{e}+02$

$1.654 \mathrm{e}+03$

$1.730 \mathrm{e}-01$

2.185e-01

6.476e-02

9.184e-01

$1.022 \mathrm{e}+02$

4.837e+03

Variable

2.503e-01

2.499e-01

2.135e-01

$1.267 e+03$

$8.770 e+01$

$3.650 e+02$

$4.557 e+00$

$2.448 e+02$

$1.059 \mathrm{e}+03$

$1.110 \mathrm{e}-01$

$1.404 \mathrm{e}-01$

4.164e-02

5. $918 \mathrm{e}-01$

$6.593 e+01$

3.096e+03

Variable

1.734e-01

$1.732 \mathrm{e}-01$

$1.480 \mathrm{e}-01$

$8.783 e+02$

$6.082 e+01$

$2.532 e+02$
Results

\section{Fluence Rate \\ $\mathrm{MeV} / \mathrm{cm}^{2} / \mathrm{sec}$ \\ With Buildup}

$8.538 e+02$

$3.307 e+03$

3.474e-01

4.478e-01

$1.350 \mathrm{e}-01$

$1.984 \mathrm{e}+00$

$2.250 \mathrm{e}+02$

$\mathbf{9 . 3 2 7 e + 0 3}$

$X$ Dose Point 1

3.956e-01

3.967e-01

3.407e-01

$2.026 \mathrm{e}+03$

$1.418 \mathrm{e}+02$

$5.973 e+02$

$1.219 e+01$

$4.812 e+02$

$1.867 e+03$

$1.964 \mathrm{e}-01$

2.538e-01

7.667e-02

$1.131 \mathrm{e}+00$

$1.287 \mathrm{e}+02$

$5.257 e+03$

$X$ Dose Point 1

2.529e-01

2.536e-01

2.178e-01

$1.296 \mathrm{e}+03$

$9.071 e+01$

$3.822 e+02$

$7.805 \mathrm{e}+00$

$3.081 \mathrm{e}+02$

$1.196 \mathrm{e}+03$

1.261e-01

1.631e-01

4.933e-02

7.296e-01

$8.316 \mathrm{e}+01$

3.365e+03

$X$ Dose Point 1

1.752e-01

$1.758 \mathrm{e}-01$

1.510e-01

$8.983 e+02$

$6.291 e+01$

$2.651 e+02$

\section{Exposure Rate $\mathrm{mR} / \mathrm{hr}$ \\ No Buildup \\ $1.199 \mathrm{e}+00$ \\ $5.559 e+00$ \\ 5.962e-04 \\ $7.574 \mathrm{e}-04$ \\ 2.228e-04 \\ 3.069e-03 \\ 3.300e-01}

$1.606 e+01$

(4 of 11 )

3.882e-03

$1.729 \mathrm{e}-03$

8.896e-04

$3.936 e+00$

2.170e-01

8.728e-01

$1.173 \mathrm{e}-02$

$6.752 \mathrm{e}-01$

$3.137 \mathrm{e}+00$

3.370e-04

4.290e-04

$1.264 \mathrm{e}-04$

1.747e-03

$1.883 e-01$

9.047e+00

(5 of 11)

2.481e-03

$1.105 \mathrm{e}-03$

5.687e-04

$2.516 \mathrm{e}+00$

1.388e-01

5.584e-01

7.505e-03

4.321e-01

$2.010 e+00$

2.162e-04

2.755e-04

8.128e-05

$1.126 \mathrm{e}-03$

1.215e-01

$\mathbf{5 . 7 9 0 e + 0 0}$

(6 of 11)

$1.719 \mathrm{e}-03$

7.661e-04

$3.943 e-04$

$1.745 e+00$

9.625e-02

3.873e-01

\section{Exposure Rate $\mathrm{mR} / \mathrm{hr}$}

With Buildup

$1.507 e+00$

$6.273 e+00$

6.768e-04

8.789e-04

2.634e-04

$3.773 e-03$

4.148e-01

1.742e+01

$(44.12 \mathrm{~cm})$

3.921e-03

$1.754 \mathrm{e}-03$

9.077e-04

$4.025 e+00$

2.244e-01

9.139e-01

2.007e-02

8.492e-01

$3.541 \mathrm{e}+00$

3.828e-04

4.982e-04

1.497e-04

2.152e-03

2.372e-01

$\mathbf{9 . 8 2 0 e}+00$

$(54.12 \mathrm{~cm})$

2.506e-03

1.122e-03

5.803e-04

$2.573 e+00$

1.435e-01

5.847e-01

$1.285 e-02$

5.437e-01

$2.269 \mathrm{e}+00$

2.456e-04

3.201e-04

9.629e-05

$1.388 \mathrm{e}-03$

1.533e-01

$\mathbf{6 . 2 8 7 e + 0 0}$

$(64.12 \mathrm{~cm})$

$1.736 \mathrm{e}-03$

$7.774 \mathrm{e}-04$

4.023e-04

$1.784 \mathrm{e}+00$

9.956e-02

4.056e-01 


$\begin{array}{cc}\begin{array}{c}\text { Energy } \\ \text { MeV }\end{array} & \begin{array}{c}\text { Activity } \\ \text { Photons/sec }\end{array} \\ 0.15 & 1.406 \mathrm{e}+08 \\ 0.2 & 2.815 \mathrm{e}+09 \\ 0.3 & 3.225 \mathrm{e}+09 \\ 0.4 & 1.427 \mathrm{e}+05 \\ 0.5 & 9.832 \mathrm{e}+04 \\ 0.6 & 1.848 \mathrm{e}+04 \\ 0.8 & 1.371 \mathrm{e}+05 \\ 1.0 & 9.709 \mathrm{e}+06 \\ \text { Totals } & \mathbf{3 . 0 6 3 e}+\mathbf{1 1} \\ & \text { Sensitivity } \\ 0.03 & 1.819 \mathrm{e}+10 \\ 0.04 & 5.381 \mathrm{e}+08 \\ 0.05 & 1.015 \mathrm{e}+08 \\ 0.06 & 2.633 \mathrm{e}+11 \\ 0.08 & 6.272 \mathrm{e}+09 \\ 0.1 & 1.176 \mathrm{e}+10 \\ 0.15 & 1.406 \mathrm{e}+08 \\ 0.2 & 2.815 \mathrm{e}+09 \\ 0.3 & 3.225 \mathrm{e}+09 \\ 0.4 & 1.427 \mathrm{e}+05 \\ 0.5 & 9.832 \mathrm{e}+04 \\ 0.6 & 1.848 \mathrm{e}+04 \\ 0.8 & 1.371 \mathrm{e}+05 \\ 1.0 & 9.709 \mathrm{e}+06 \\ \text { Totals } & \mathbf{3 . 0 6 3 e}+11\end{array}$

Totals $\quad 3.063 e+11$

Sensitivity

$0.03 \quad 1.819 e+10$

$0.04 \quad 5.381 e+08$

$0.05 \quad 1.015 e+08$

$0.06 \quad 2.633 e+11$

$0.08 \quad 6.272 e+09$

$0.1 \quad 1.176 \mathrm{e}+10$

$0.15 \quad 1.406 e+08$

$0.2 \quad 2.815 e+09$

$0.3 \quad 3.225 e+09$

$0.4 \quad 1.427 e+05$

$0.5 \quad 9.832 e+04$

$0.6 \quad 1.848 e+04$

$0.8 \quad 1.371 \mathrm{e}+05$

$1.0 \quad 9.709 \mathrm{e}+06$

Totals $\quad 3.063 e+11$

Sensitivity

$0.03 \quad 1.819 e+10$

$0.04 \quad 5.381 e+08$

$0.05 \quad 1.015 e+08$

$0.06 \quad 2.633 e+11$

$0.08 \quad 6.272 e+09$

\section{Fluence Rate $\mathrm{MeV} / \mathrm{cm}^{2} / \mathrm{sec}$}

No Buildup

$3.162 \mathrm{e}+00$

$1.699 \mathrm{e}+02$

$7.359 e+02$

$7.713 e-02$

$9.766 \mathrm{e}-02$

2.900e-02

4.127e-01

$4.603 e+01$

$2.148 e+03$

Variable

1.270e-01

$1.270 \mathrm{e}-01$

$1.085 \mathrm{e}-01$

$6.441 e+02$

$4.462 e+01$

$1.858 \mathrm{e}+02$

$2.320 \mathrm{e}+00$

$1.247 e+02$

$5.405 e+02$

$5.669 \mathrm{e}-02$

$7.182 \mathrm{e}-02$

2.134e-02

3.040e-01

$3.393 e+01$

1.577e+03

Variable

9.692e-02

9.697e-02

8.292e-02

$4.922 \mathrm{e}+02$

$3.410 \mathrm{e}+01$

$1.420 \mathrm{e}+02$

$1.774 \mathrm{e}+00$

$9.539 \mathrm{e}+01$

$4.136 e+02$

4.340e-02

5.501e-02

1.635e-02

2.332e-01

$2.604 e+01$

\section{$1.206 e+03$}

Variable

7.631e-02

7.642e-02

6.537e-02

$3.881 e+02$

$2.690 e+01$
Results

\section{Fluence Rate \\ $\mathrm{MeV} / \mathrm{cm}^{2} / \mathrm{sec}$}

With Buildup

$5.419 \mathrm{e}+00$

$2.139 e+02$

$8.310 e+02$

8.765e-02

$1.135 \mathrm{e}-01$

3.437e-02

5.092e-01

$5.811 e+01$

2.336e+03

$X$ Dose Point 1

$1.283 e-01$

$1.289 \mathrm{e}-01$

1.107e-01

$6.588 \mathrm{e}+02$

$4.615 e+01$

$1.945 e+02$

$3.980 e+00$

$1.571 \mathrm{e}+02$

$6.105 e+02$

6.443e-02

8.351e-02

2.530e-02

3.753e-01

$4.288 \mathrm{e}+01$

$1.715 e+03$

$X$ Dose Point 1

9.790e-02

9.841e-02

8.460e-02

$5.035 e+02$

$3.528 \mathrm{e}+01$

$1.487 e+02$

$3.046 \mathrm{e}+00$

$1.202 \mathrm{e}+02$

$4.672 e+02$

4.934e-02

$6.398 \mathrm{e}-02$

1.940e-02

2.880e-01

3. $293 e+01$

$1.312 \mathrm{e}+03$

$X$ Dose Point 1

7.708e-02

$7.756 \mathrm{e}-02$

6.670e-02

$3.970 \mathrm{e}+02$

$2.783 e+01$

\section{Exposure Rate $\mathrm{mR} / \mathrm{hr}$ \\ No Buildup}

5.207e-03

2.999e-01

$1.396 \mathrm{e}+00$

$1.503 \mathrm{e}-04$

$1.917 \mathrm{e}-04$

5.660e-05

$7.849 \mathrm{e}-04$

$8.484 \mathrm{e}-02$

$4.018 e+00$

(7 of 11)

$1.259 \mathrm{e}-03$

$5.615 \mathrm{e}-04$

2.891e-04

$1.279 \mathrm{e}+00$

$7.061 \mathrm{e}-02$

2.842e-01

$3.821 \mathrm{e}-03$

2.201e-01

$1.025 \mathrm{e}+00$

$1.105 \mathrm{e}-04$

$1.410 \mathrm{e}-04$

$4.165 \mathrm{e}-05$

$5.782 \mathrm{e}-04$

$6.255 \mathrm{e}-02$

$2.949 e+00$

(8 of 11)

9.606e-04

4.289e-04

2.209e-04

9.777e-01

5.397e-02

2.173e-01

2.921e-03

$1.684 \mathrm{e}-01$

$7.845 \mathrm{e}-01$

$8.456 \mathrm{e}-05$

$1.080 \mathrm{e}-04$

3.192e-05

$4.435 \mathrm{e}-04$

4.801e-02

2.255e+00

(9 of 11)

7.563e-04

$3.380 \mathrm{e}-04$

$1.741 \mathrm{e}-04$

$7.709 \mathrm{e}-01$

4.256e-02

\section{Exposure Rate $\mathrm{mR} / \mathrm{hr}$}

With Buildup

8.924e-03

3.775e-01

$1.576 \mathrm{e}+00$

$1.708 \mathrm{e}-04$

$2.228 \mathrm{e}-04$

6.709e-05

9.685e-04

$1.071 \mathrm{e}-01$

4.364e+00

$(74.12 \mathrm{~cm})$

$1.272 \mathrm{e}-03$

5.699e-04

2.950e-04

$1.309 e+00$

7.304e-02

2.976e-01

6.554e-03

2.772e-01

$1.158 \mathrm{e}+00$

$1.255 \mathrm{e}-04$

1.639e-04

4.939e-05

7.139e-04

7.904e-02

$3.203 e+00$

$(84.12 \mathrm{~cm})$

9.702e-04

4.352e-04

2.254e-04

$1.000 \mathrm{e}+00$

5.583e-02

2.276e-01

5.015e-03

2.121e-01

8.862e-01

9.613e-05

$1.256 \mathrm{e}-04$

3.786e-05

5.479e-04

6.070e-02

$\mathbf{2 . 4 5 0 e + 0 0}$

$(94.12 \mathrm{~cm})$

7.639e-04

3.430e-04

$1.777 e-04$

$7.886 e-01$

4.404e-02 


\begin{tabular}{|c|c|c|c|c|c|}
\hline $\begin{array}{c}\text { Energy } \\
\text { MeV }\end{array}$ & $\begin{array}{c}\text { Activity } \\
\text { Photons/sec }\end{array}$ & $\begin{array}{c}\text { Fluence Rate } \\
\text { MeV/cm²/sec } \\
\text { No Buildup }\end{array}$ & $\begin{array}{l}\text { Fluence Rate } \\
\text { MeV/cm²/sec } \\
\text { With Buildup }\end{array}$ & $\begin{array}{c}\text { Exposure Rate } \\
\text { mR/hr } \\
\text { No Buildup }\end{array}$ & $\begin{array}{c}\text { Exposure Rate } \\
\text { mR/hr } \\
\text { With Buildup }\end{array}$ \\
\hline 0.1 & $1.176 \mathrm{e}+10$ & $1.120 \mathrm{e}+02$ & $1.173 e+02$ & $1.714 \mathrm{e}-01$ & $1.795 e-01$ \\
\hline 0.15 & $1.406 \mathrm{e}+08$ & $1.400 e+00$ & $2.405 e+00$ & $2.305 e-03$ & $3.960 e-03$ \\
\hline 0.2 & $2.815 e+09$ & $7.528 e+01$ & $9.485 e+01$ & $1.329 \mathrm{e}-01$ & $1.674 \mathrm{e}-01$ \\
\hline 0.3 & $3.225 e+09$ & $3.265 e+02$ & $3.689 e+02$ & $6.194 \mathrm{e}-01$ & $6.998 e-01$ \\
\hline 0.4 & $1.427 e+05$ & $3.428 e-02$ & $3.898 e-02$ & $6.679 e-05$ & $7.594 \mathrm{e}-05$ \\
\hline 0.5 & $9.832 e+04$ & $4.347 e-02$ & $5.057 e-02$ & $8.533 e-05$ & $9.927 e-05$ \\
\hline 0.6 & $1.848 \mathrm{e}+04$ & $1.293 e-02$ & $1.534 \mathrm{e}-02$ & $2.523 e-05$ & $2.994 e-05$ \\
\hline 0.8 & $1.371 \mathrm{e}+05$ & $1.844 \mathrm{e}-01$ & $2.279 \mathrm{e}-01$ & $3.508 e-04$ & $4.336 e-04$ \\
\hline 1.0 & $9.709 e+06$ & $2.061 e+01$ & $2.608 e+01$ & $3.800 e-02$ & $4.806 e-02$ \\
\hline \multirow[t]{2}{*}{ Totals } & $3.063 e+11$ & $9.514 \mathrm{e}+02$ & $1.035 e+03$ & $1.779 e+00$ & $1.933 e+00$ \\
\hline & Sensitivity & Variable & X Dose Point 1 & (10 of 11 ) & $(104.12 \mathrm{~cm})$ \\
\hline 0.03 & $1.819 e+10$ & $6.159 e-02$ & $6.220 e-02$ & $6.103 e-04$ & $6.165 e-04$ \\
\hline 0.04 & $5.381 e+08$ & $6.174 e-02$ & $6.266 e-02$ & $2.731 \mathrm{e}-04$ & $2.771 \mathrm{e}-04$ \\
\hline 0.05 & $1.015 e+08$ & $5.283 e-02$ & $5.391 e-02$ & $1.407 e-04$ & $1.436 \mathrm{e}-04$ \\
\hline 0.06 & $2.633 e+11$ & $3.137 e+02$ & $3.209 e+02$ & $6.232 \mathrm{e}-01$ & $6.374 e-01$ \\
\hline 0.08 & $6.272 e+09$ & $2.175 e+01$ & $2.250 e+01$ & $3.441 e-02$ & $3.561 e-02$ \\
\hline 0.1 & $1.176 \mathrm{e}+10$ & $9.059 e+01$ & $9.490 e+01$ & $1.386 \mathrm{e}-01$ & $1.452 \mathrm{e}-01$ \\
\hline 0.15 & $1.406 \mathrm{e}+08$ & $1.132 \mathrm{e}+00$ & $1.947 e+00$ & $1.864 \mathrm{e}-03$ & $3.205 e-03$ \\
\hline 0.2 & $2.815 e+09$ & $6.090 e+01$ & $7.676 e+01$ & $1.075 e-01$ & $1.355 e-01$ \\
\hline 0.3 & $3.225 e+09$ & $2.642 e+02$ & $2.986 e+02$ & $5.012 e-01$ & $5.665 e-01$ \\
\hline 0.4 & $1.427 e+05$ & $2.775 e-02$ & $3.156 \mathrm{e}-02$ & $5.408 e-05$ & $6.149 e-05$ \\
\hline 0.5 & $9.832 e+04$ & $3.521 \mathrm{e}-02$ & $4.097 e-02$ & $6.911 e-05$ & $8.041 e-05$ \\
\hline 0.6 & $1.848 e+04$ & $1.047 e-02$ & $1.243 e-02$ & $2.044 \mathrm{e}-05$ & $2.426 \mathrm{e}-05$ \\
\hline 0.8 & $1.371 e+05$ & $1.495 \mathrm{e}-01$ & $1.849 \mathrm{e}-01$ & $2.844 \mathrm{e}-04$ & $3.516 e-04$ \\
\hline 1.0 & $9.709 e+06$ & $1.672 \mathrm{e}+01$ & $2.116 e+01$ & $3.081 \mathrm{e}-02$ & $3.900 \mathrm{e}-02$ \\
\hline \multirow[t]{2}{*}{ Totals } & $3.063 e+11$ & $7.695 e+02$ & $8.373 e+02$ & $1.439 e+00$ & $1.564 \mathrm{e}+00$ \\
\hline & Sensitivity & Variable & $X$ Dose Point 1 & (11 of 11$)$ & $(114.12 \mathrm{~cm})$ \\
\hline 0.03 & $1.819 \mathrm{e}+10$ & $5.071 \mathrm{e}-02$ & $5.122 \mathrm{e}-02$ & $5.025 e-04$ & $5.076 \mathrm{e}-04$ \\
\hline 0.04 & $5.381 e+08$ & $5.089 e-02$ & $5.164 \mathrm{e}-02$ & $2.251 \mathrm{e}-04$ & $2.284 \mathrm{e}-04$ \\
\hline 0.05 & $1.015 e+08$ & $4.356 \mathrm{e}-02$ & $4.445 e-02$ & $1.160 \mathrm{e}-04$ & $1.184 \mathrm{e}-04$ \\
\hline 0.06 & $2.633 e+11$ & $2.587 e+02$ & $2.647 e+02$ & $5.139 e-01$ & $5.257 e-01$ \\
\hline 0.08 & $6.272 e+09$ & $1.794 \mathrm{e}+01$ & $1.856 \mathrm{e}+01$ & $2.839 e-02$ & $2.938 e-02$ \\
\hline 0.1 & $1.176 \mathrm{e}+10$ & $7.474 \mathrm{e}+01$ & $7.831 e+01$ & $1.143 e-01$ & $1.198 \mathrm{e}-01$ \\
\hline 0.15 & $1.406 \mathrm{e}+08$ & $9.342 \mathrm{e}-01$ & $1.608 \mathrm{e}+00$ & $1.538 \mathrm{e}-03$ & $2.647 e-03$ \\
\hline 0.2 & $2.815 e+09$ & $5.027 e+01$ & $6.337 e+01$ & $8.872 \mathrm{e}-02$ & $1.119 \mathrm{e}-01$ \\
\hline 0.3 & $3.225 e+09$ & $2.182 \mathrm{e}+02$ & $2.466 e+02$ & $4.138 \mathrm{e}-01$ & $4.678 e-01$ \\
\hline 0.4 & $1.427 e+05$ & $2.292 \mathrm{e}-02$ & $2.607 e-02$ & $4.466 e-05$ & $5.080 e-05$ \\
\hline 0.5 & $9.832 e+04$ & $2.909 e-02$ & $3.385 e-02$ & $5.709 e-05$ & $6.645 e-05$ \\
\hline 0.6 & $1.848 e+04$ & $8.655 e-03$ & $1.028 e-02$ & $1.689 e-05$ & $2.006 e-05$ \\
\hline 0.8 & $1.371 e+05$ & $1.236 \mathrm{e}-01$ & $1.529 \mathrm{e}-01$ & $2.351 \mathrm{e}-04$ & $2.908 e-04$ \\
\hline 1.0 & $9.709 e+06$ & $1.383 e+01$ & $1.751 e+01$ & $2.549 e-02$ & $3.227 e-02$ \\
\hline Totals & $3.063 e+11$ & $6.350 e+02$ & $6.910 e+02$ & $1.187 e+00$ & $1.291 \mathrm{e}+00$ \\
\hline
\end{tabular}

